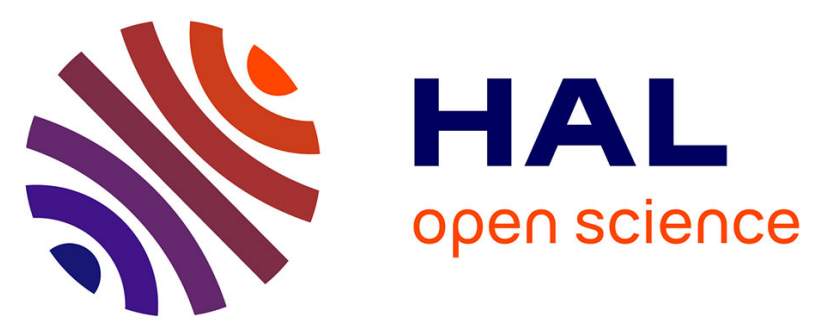

\title{
Patterns of organic carbon enrichment in a lacustrine system across the K-T boundary: Insight from a multi-proxy analysis of the Yacoraite Formation, Salta rift basin, Argentina
}

Rohais Sébastien, Hamon Youri, Deschamps Rémy, Beaumont Valérie, Marta Gasparrini, Romero-Sarmiento Maria

\section{To cite this version:}

Rohais Sébastien, Hamon Youri, Deschamps Rémy, Beaumont Valérie, Marta Gasparrini, et al.. Patterns of organic carbon enrichment in a lacustrine system across the $\mathrm{K}-\mathrm{T}$ boundary: Insight from a multi-proxy analysis of the Yacoraite Formation, Salta rift basin, Argentina. International Journal of Coal Geology, 2019, 210, pp.103208. 10.1016/j.coal.2019.05.015 . hal-02397853

\section{HAL Id: hal-02397853 \\ https://hal-ifp.archives-ouvertes.fr/hal-02397853}

Submitted on 6 Dec 2019

HAL is a multi-disciplinary open access archive for the deposit and dissemination of scientific research documents, whether they are published or not. The documents may come from teaching and research institutions in France or abroad, or from public or private research centers.
L'archive ouverte pluridisciplinaire HAL, est destinée au dépôt et à la diffusion de documents scientifiques de niveau recherche, publiés ou non, émanant des établissements d'enseignement et de recherche français ou étrangers, des laboratoires publics ou privés. 
Patterns of organic carbon enrichment in a lacustrine system across the K-T boundary: Insight from a multi-proxy analysis of the Yacoraite Formation, Salta rift basin, Argentina

Rohais Sébastien $(1, *)$, Hamon Youri (1), Deschamps Rémy (1), Beaumont Valérie (1), Gasparrini Marta (1), Pillot Daniel (1), Romero-Sarmiento Maria (1)

(1) IFPEN, Direction Géosciences, 1 et 4 Avenue de Bois-Préau, 92852 Rueil-Malmaison Cedex. France *e-mail address of corresponding author: sebastien.rohais@ifpen.fr

Keywords: source rock, organic carbon, K-T boundary, lacustrine, Salta rift, Argentina, source-to-sink Highlights:

How K-T crisis is recorded in lacustrine system?

Is carbonate $\delta^{13} \mathrm{C}$ negative anomaly recording the K-T necessarily a shut-down of paleoproductivity?

K-T crisis has a significant impact on lacustrine organic matter distribution (TOC, HI)

Conceptual model for organic carbon enrichment in lacustrine sedimentary systems

\section{Abstract}

In this study, an integrated approach was applied using available sedimentary, geochronology, geochemical and isotopic datasets to better understand the complex interactions between production, destruction, and dilution processes that characterize the organic-rich sediments dynamic across the K-T boundary in a lacustrine system. This approach was tested here on the Late Cretaceous to Early Cenozoic Yacoraite Formation, a typical lacustrine source rock from the Salta rift 
Basin (NW Argentina). The Yacoraite Formation corresponds to a mixed carbonate-siliciclastic lacustrine sedimentary system, deposited during the sag phase (post-rift). We demonstrated here that new ashes $\mathrm{U}-\mathrm{Pb}$ dating tie the $\mathrm{K}-\mathrm{T}$ boundary during the deposition of the Yacoraite Formation.

The Yacoraite Formation recorded major climate changes that can be documented in terms of catchment dynamic, erosion processes, carbonate accumulation trends, lacustrine dynamic and source rock quality. The pattern of organic carbon enrichment in the Yacoraite Formation illustrates how a biological pump came across a major climatic change. The background organic matter correspond to Type I dominated by algal growth (mean HI 600-800 mgHC/gTOC, TOC 0 1-2 wt.\%). The K-T boundary was the climax of a climate change initiated ca. 0.3 Myr before and induced a major change in the catchment weathering processes, which temporally corresponds to the accumulation of poor quality source rock intervals $\left(\mathrm{TOC}_{0} \leq 0.2 \mathrm{wt} . \%\right.$ and $\mathrm{HI}<50 \mathrm{mgHC} / \mathrm{gTOC}$ ) in these series. The K$\mathrm{T}$ boundary is highlighted by the main negative anomaly in $\delta^{13} \mathrm{C}$ of the carbonate deposits of the Yacoraite Formation. It was followed by a major pulse in paleoproductivity, itself followed by a major pulse in $\mathrm{TOC}_{0}(10-15$ wt.\%) under anoxia conditions. In ca. 0.2 Myr the lacustrine dynamic and its related organic-carbon enrichment resumed to their initial setting, just prior to the preluding $\mathrm{K}-\mathrm{T}$ boundary climate change. Results suggest that the Yacoraite Formation can be considered as a world-class example to illustrate how the K-T boundary is recorded in lacustrine sediments.

\section{Introduction}

The Cretaceous-Tertiary (K-T) boundary has been studied for many years through multi-disciplinary approaches to understand the relationship between climate and paleo-environmental changes, and how they are preserved in the geological record. The K-T boundary is dated to $65.5 \pm 0.3 \mathrm{Ma}$ according to the most recent version of the International Commission on Stratigraphy (Cohen et al., 2013). Practically, the occurrence of the K-T boundary in a sedimentary series is invoked when a $\delta^{13} \mathrm{C}$ negative anomaly, and/or an iridium positive anomaly, and/or ejecta debris from extra-terrestrial body (Alvarez et al., 1980) are detected in a stratigraphic interval potentially encompassing the K-T 
(Meyers, 1992 and references herein). However, most works addressing the K-T boundary location and its impact on climate and paleo-environmental changes are biased by the lack of sufficiently resolved geochronology data integrated in a basin-scale study. This hinders to properly localize the KT (Renne et al., 2013) and consequently to gain consistent understanding of the K-T effects on the sedimentary basin dynamics.

Debates are still persisting regarding how the K-T crisis impacts (1) primary productivity (e.g., Hsu and McKenzie, 1985; Brinkhuis and Zachariasse, 1988; Vellekoop et al., 2016), (2) catchment erosion processes and resulting sediment supply, especially in response to vegetation cover (Mayor et al., 2013; Kaiho et al., 2016) and (3) paleo-environmental parameters such as temperature, redox and trophic conditions (e.g., Brinkhuis and Zachariasse, 1988; Speijer and Van der Zwaan, 1996; Brinkhuis et al., 1998). Considering that the three main mechanisms commonly inferred to control organiccarbon enrichment in source rock deposits are (1) production (i.e. primary productivity), (2) dilution (i.e. sediment supply), and (3) preservation (i.e. redox conditions) (Schwarzkopf 1993; Carroll and Bohacs, 1999; Bohacs et al. 2000; Harris et al., 2004; Katz, 2005; Bohacs et al., 2005), source rock deposits are probably the most suitable alternative to document the K-T crisis record in sediments.

Most concepts and knowledge for the influence of the K-T boundary on organic-carbon enrichment are derived from marine case studies (e.g. Claeys et al., 2002). However, marine environments are, not necessarily the most suitable examples to document the influence of the K-T on both climate and surface processes because of the response time-lapse characterizing the source-to-sink system. Indeed, the response time for ocean masses equilibrium, as well as the buffering effect related to the depositional profile length could induce a time shift in the cause-to-effect record. In contrast, continental and more particularly lacustrine examples, may represent exceptional records of the K-T crisis because the climate related dynamics of the catchment rocks is quickly transferred and recorded in the lake sediments. Furthermore, the size and nature of these sedimentary systems (i.e. closed systems of relatively small size) make it possible to establish sedimentary budget analysis, 
more confidently than on a marine setting such as passive margin for example. Recent studies on lacustrine organic rich deposits document their high potential record for the characterization of paleoclimate, paleoenvironmental conditions, provenance and drainage system (Ma et al., 2015; Tao et al., 2017; Zhang et al., 2017).

The purpose of this contribution is to integrate sedimentary, geochronology, organic, elemental and isotopic geochemistry datasets to define how the K-T boundary is recorded in a lacustrine system evaluating the pattern of organic-carbon enrichment. Herein, this integrated approach is applied to the Late Cretaceous to Early Cenozoic Yacoraite Formation, a typical lacustrine source rock from the Salta rift Basin (Argentina).

\section{The Yacoraite Formation - Salta rift Basin}

\subsection{Generalities}

The Salta rift Basin is part of the Cretaceous-Paleocene Andean basin system of central-western South America (Figure 1). The Yacoraite Formation overlies the Lecho Formation mainly consisting in aeolian to fluvial deposits, and is overlaid by the Tunal Formations, mainly composed of playa evaporite-bearing claystone (Figure 2). The Yacoraite Formation was deposited during the sag phase of the rifting, and recorded in a wide depocenter in the studied area that overlapped the two main pre-existing syn-rift depocenters (Alemania and Metán sub-basins), with maximum thicknesses in the central part of the basin nearby the Guachipas paleohigh (Figure 1). The age of the Yacoraite Formation is Maastrichtian to Danian based on Senonian dinosaur tracks (Alonso and Marquillas, 1986) and Maastrichtian and Danian palynomorphs (Moroni, 1982).

\subsection{Sedimentology and stratigraphy}

In this study, we mainly refer to detailed works previously presented in Paquette et al. (2015), Deschamps et al. (2017), Romero-Sarmiento et al. (2019) dedicated to the sedimentology, stratigraphy and characterization of the Yacoraite Formation. This study takes benefit of previous in- 
house detailed stratigraphic works from the Joint Industrial Project COMPAS led by IFPEN from 2012 to 2015 . We focus on the basic elements and building blocks resulting from these previous studies in order to present the sequence stratigraphic framework used as reference hereafter (Figure 2).

The depositional model for the Yacoraite Formation can be subdivided into two end-members: a siliciclastic-dominated and a carbonate-dominated member. The mixing of both sources is possible, thus resulting in mixed facies. The siliciclastic-dominated facies are mainly located along previous footwall margins, whereas the carbonate-dominated ones preferentially occur in paleo-highs away from siliciclastic inputs (Figure 3).

The Yacoraite Formation recorded an overall transgressive trend up to the MFS3 (maximum of backstep of the depositional system) followed up by a prograding, filling up trend (Figure 2). This formation can be subdivided into four main sequences (Figure 2). Assuming a 5 Myr duration, these four sequences can then be considered as "third-order" sequences organized within a "secondorder" sequence (Figure 2). The four main sequences are organized with similar internal architectures, from base to top: (1) a major sequence boundary (SB) characterized by a major basinward shift of the depositional system with common exposures, (2) an aggrading trend of the shallow depositional system, mainly preserved in the basin depocenter, (3) a transgressive trend characterized by a backstep of the depositional system and an overall increase in the bathymetry in the central part of the basin, (4) a maximum flooding surface (MFS) characterized by a major backstep of the depositional system and the maximum of extension of the "deepest" facies association, and finally (5) a prograding/aggrading trend characterized by a basinward shift of the depositional system and a decrease in the bathymetry. Sequence 1 is subdivided into four "fourthorder" sequences (1a, 1b, 1c, 1d) organized in transgressive and regressive trends (Figure 2). Sequence 2 is subdivided into three "fourth-order" sequences $(2 a, 2 b, 2 c)$, sequence 3 in two "fourth-order" sequences (3a, 3b) and sequence 4 in two "fourth-order" sequences (4a, 4b) (Figure 2). Assuming a bathymetric range of 0 to $40 \mathrm{~m}$ in water depth based on sedimentological criteria and 
geometrical relationship, the stratigraphic architecture was converted into a relative lake level (Figure 2).

\section{Materials and methods}

An integrated approach is proposed in this study using available sedimentary, geochronology, geochemical and isotopic datasets to better describe the organic carbon enrichment across the K-T boundary in a lacustrine system. To illustrate the organic, elemental and isotopic geochemistry results of this study, we choose to project all the analysis coming from twelve measured sections in a radius of $10 \mathrm{~km}$ along a reference sedimentological section (Figure 2, see also location in Figure 1). Such projections are based on high-resolution stratigraphic correlations previously carried out by the co-authors (e.g. Deschamps et al., 2017). The complete dataset including 255 Rock-Eval ${ }^{\circledR} 6$ analysis, 114 samples for major and trace elements using ICP-MS, 8 U-Pb datings on zircon, 159 samples for $\delta^{13} \mathrm{C}$ on carbonate, is provided as supplementary material.

The proposed approach aims at qualifying, and when possible, quantifying the three mechanisms ruling the deposition of organic-rich sediments: (i) dilution, (ii) production, (iii) preservation. The very first step was dedicated to characterize the pattern of organic-carbon enrichment. Total Organic Carbon (TOC) measurements were performed on 255 outcrop and core samples $(50 \mathrm{mg}$ of ground/powdered rock) using a Rock-Eval ${ }^{\circledR} 6$ device operated at the IFPEN geochemistry laboratory (France) following the procedure described in Behar et al. (2001). As the investigated rock samples did not show in-situ liquid hydrocarbons (Romero et al., 2019), Rock-Eval ${ }^{\circledR}$ analysis were carried out using the classical IFP Basic/Bulk-Rock ${ }^{\mathrm{TM}}$ method mainly dedicated to analyze conventional source rocks. The classical present-day Rock-Eval S1, S2 and S3 parameters were determined and the mineral carbon MinC (wt.\%), total organic content (TOC), hydrogen index (HI), oxygen index (OI) were calculated. $\mathrm{HI}$ and $\mathrm{Ol}$ were calculated only when $\mathrm{TOC} \geq 0.2 \mathrm{wt} . \%$. The original total organic carbon $\left(\mathrm{TOC}_{0}\right)$ at the deposition environment was restored based on empirical formula (Equation 1) 
and abacus as well as conceptual petroleum models (e.g. Espitalié et al., 1986; Jarvie et al., 2007; Romero-Sarmiento et al., 2013).

$T O C_{0}=\frac{H I\left(\frac{T O C}{1+k}\right)(83.33)}{\left(H I_{0}\left(1-T R H \mathrm{HI}\left(83.33-\left(\frac{T O C}{1+k}\right)\right)\right)-\left(H I\left(\frac{T O C}{1+k}\right)\right)\right.} \quad$ (Equation 1)

where $\mathrm{TOC}=$ total organic carbon at present day $(\mathrm{wt} . \%), \mathrm{HI}$ (hydrogen index at present day) = remaining potential (S2) divided by TOC $\times 100$ (in $\mathrm{mg} \mathrm{HC} / \mathrm{g} \mathrm{TOC}$ ), where 83.33 is the average carbon content in hydrocarbons and $\mathrm{k}$ is a correction factor based on residual organic carbon being enriched in carbon over original values at high thermal maturity (Burnham, 1989). For Type I kerogen the increase in residual carbon CR at high thermal maturity is 50\% (Burnham, 1989). The correction factor, $k$, is then $\mathrm{TR}_{\mathrm{HI}} \times \mathrm{CR}$. $\mathrm{TR}_{\mathrm{HI}}=$ transformation or conversion ratio calculated from $\mathrm{HI}_{0}$ and $\mathrm{HI}$ with the following equation (Equation 2):

$T R_{\mathrm{HI}}=1-\frac{H I\left(1200-H I_{0}\left(1-P I_{0}\right)\right)}{H I_{0}(1200-H I(1-P I))} \quad($ Equation 2)

with PI (production index at present day) = free oil content as measured by S1 only divided by the sum of S1 plus the remaining generation potential (S2) or S1/(S1 + S2) (values from 0.0 to 1.0), with $\mathrm{S} 1=$ a part of free volatile hydrocarbons thermally flushed from a rock sample at $300{ }^{\circ} \mathrm{C}$ (in $\mathrm{mg} \mathrm{HC} / \mathrm{g}$ rock), $\mathrm{S} 2$ = hydrocarbon compounds released from the thermal cracking of sedimentary organic matter (kerogen) during standard Rock-Eval pyrolysis detected between 300 and $650{ }^{\circ} \mathrm{C}$ ) (in $\mathrm{mg} \mathrm{HC} / \mathrm{g}$ rock). $\mathrm{Pl}_{0}=0.02$ (Peters et al., 2006). The value of $\mathrm{HI}_{0}$ used in this study is $800 \mathrm{mg} \mathrm{HC} / \mathrm{g} \mathrm{TOC}$ as suggested by the most immature sample (see supplementary material).

(i) Dilution were then addressed by carrying out a 3D sedimentary budget analysis using high resolution correlations (23 surfaces) and restored stratigraphic architecture. This work takes benefit of previous stratigraphic works (e.g. Deschamps et al., 2017; Romero-Sarmiento et al., 2019). A total of 48 measured sections were used to restore the stratigraphic architecture, including cross-sections, thickness and paleogeography maps at basin-scale. Sediment supply, accumulation rates and 
associated uncertainties were then quantified using the same procedure described in Rohais et al. (2016). This approach aims at quantifying carbonate accumulation rates for proximal (carbonatedominated margin) and distal environments (offshore-profundal depositional setting) as well as the sediment supply (Qs) derived from the siliciclastic-dominated margin. Rates were quantified using new $\mathrm{U}-\mathrm{Pb}$ dating of zircon from ash layers occurring within the lacustrine sedimentary pile of the Yacoraite Formation. Twelve samples ( $2 \mathrm{~kg}$ each) were prepared and analyzed at the Laboratoire Magmas \& Volcans (France), following the procedure described in Paquette and Tiepolo (2007), Müller et al. (2009), Hurai et al. (2010) and), accordingly. Zircons grains were isolated to extract the inherited signal (Paquette et al., 2015). Accurate ages were established using only ash layers with more than 8 zircon grains derived from the most recent volcanic event.

In this study, minor and trace elements were analyzed (37 elements) on 1-5 mg of ground/powdered sample by Inductively Coupled Plasma Mass Spectrometry (ICP-MS) at Bureau Veritas Commodities Canada $\mathrm{Ltd} . \mathrm{K} / \mathrm{Al}$ and $\mathrm{Ti} / \mathrm{Al}$ ratios have been used as proxies for the reconstruction of detrital input, with the differentiation between fluvial contribution (K/Al, Chester et al., 1977), and eolian transport (Ti/Al, Pye, 1987). Additionally, the Chemical Index of Alteration (CIA, Nesbitt and Young, 1982; Equation 3) was computed to document the maturity of siliciclastic sediments, as a proxy for weathering in the catchment areas. $\mathrm{ClA}^{*}$ was also computed (Equation 4) as the $\mathrm{CaO}$ concentration is not always easy to estimate properly in dolomite-rich setting (Tripathy et al., 2014). Very low $\mathrm{ClA}$ * and $\mathrm{CIA}$ lower than $50 \%$ generally indicate poorly matured and weathered material.

$$
\mathrm{CIA}=100\left(\frac{\mathrm{Al}_{2} \mathrm{O}_{3}}{\mathrm{Na}_{2} \mathrm{O}+\mathrm{K}_{2} \mathrm{O}+\mathrm{CaO}+\mathrm{Al}_{2} \mathrm{O}_{3}}\right) \quad \text { (Equation 3) }
$$

$$
C I A *=100\left(\frac{\mathrm{Al}_{2} \mathrm{O}_{3}}{\mathrm{Na}_{2} \mathrm{O}+\mathrm{K}_{2} \mathrm{O}+\mathrm{Al}_{2} \mathrm{O}_{3}}\right) \quad \text { (Equation 4) }
$$

(ii) Production, or primary production, or paleoproductivity is defined as the result of photosynthesis that controls both the amount of particulate and dissolved organic matter available to the sedimentary system (e.g. Cushing and Walsh, 1976; Toggweiler, 1989). This parameter is commonly 
difficult to quantify, and most of the studies just provide qualitative information using elementary analysis (e.g. Crombez et al., 2016). The abundance of $\mathrm{Ni}$ and $\mathrm{Cu}$ in sediments can serve as a marker of a relatively high OM flux, associated to nutrient input variation in the basin (Whitfield, 2002; Tribovillard et al., 2006). They could even be considered as better proxies to reflect primary organic productivity variations than $\mathrm{P}$ and $\mathrm{Ba}$ (Tribovillard et al., 2006). In this study, we choose to plot four proxies $(\mathrm{P} / \mathrm{Ti}, \mathrm{Ba} / \mathrm{Al}, \mathrm{Ni} / \mathrm{Al}$ and $\mathrm{Cu} / \mathrm{Al})$ along our reference section to highlight period of potential high paleoproductivity when at least two of them recorded a significant increase.

(iii) Preservation, or destruction, or reduction corresponds to the rates of degradation of organic matter in sediments (redox conditions). Numerous trace elements were extensively used in the literature as redox proxies to interpret oxygenation conditions at time of sediment deposition (e.g. Wignall and Myers, 1988; Nagao and Nakashima, 1992; Hatch and Leventhal, 1992; Calvert and Pedersen, 1993; Jones and Manning, 1994; Powell et al., 2003; Tribovillard et al., 2006; Ma et al., 2016; Zhang et al., 2017). In this study, redox conditions were assessed by combining four complementary ratios $(\mathrm{U} / \mathrm{Th}, \mathrm{V} / \mathrm{Cr}, \mathrm{Ni} / \mathrm{Co}$ and $\mathrm{V} /(\mathrm{V}+\mathrm{Ni}))$ to discriminate period with strong anoxia highlighted when the four ratios are higher than the anoxia cut-off.

Additionally, $\delta^{13} \mathrm{C}$ analysis were performed on carbonate-dominated rocks to identify a major negative anomaly and confirm the location of the K-T boundary. Matrix samples were carefully sampled using a dental drill. 159 samples were analyzed at the GeoZentrum Nord-Bayern of the Erlangen-Nürnmerg Univerity (Germany). Carbonate powders were reacted with 100\% phosphoric acid at $70^{\circ} \mathrm{C}$ using a Gasbench II connected to a ThermoFisher Delta V Plus mass spectrometer. All values are reported in per mil relative to V-PDB. Reproducibility and accuracy was monitored by replicate analysis of laboratory standards calibrated by assigning $\delta^{13} \mathrm{C}$ values of $+1.95 \%$ to NBS19 and $-46.6 \%$ to LSVEC and $\delta^{18} \mathrm{O}$ values of $-2.20 \%$ o to NBS19 and $-23.2 \%$ o to NBS18. Reproducibility for $\delta^{13} \mathrm{C}$ and $\delta^{18} \mathrm{O}$ better than \pm 0.08 .

\section{Results}




\subsection{Age of the Yacoraite Formation and K-T boundary}

As contradictory results based on ash and tuff layers $\mathrm{U}-\mathrm{Pb}$ dating in the Yacoraite Fm. have been published by Marquillas et al. (2011) to locate the K-T boundary previously identified by Sial et al. (2001) and Marquillas et al. (2007), complementary analysis have been conducted in the frame of this study. Results are presented in Table 1.

The base of the Yacoraite Formation, i.e. its contact with the underlying Lecho Fm. (Figure 2), was not directly dated. The oldest age obtained at the base of the Yacoraite Formation (base of sequence 1, Figure 2) corresponds to reworked tuff/ash layers dated at $69.1 \pm 0.7 \mathrm{Ma}$ (Table 1 ). Considering that this layers is reworked, the age of the base of the Yacoraite Formation is probably slightly older than 69.1 $\pm 0.7 \mathrm{Ma}$. The top of the Yacoraite Formation, i.e. its contact with the overlying Tunal Fm. was neither directly dated. We extrapolate the age trend assuming a relative constant sedimentation rate of $40-45 \mathrm{~m} / \mathrm{Myr}$ to attribute an age of $64 \mathrm{Ma}$ to the top of the Yacoraite Formation (Figure 2). According to our results, the K-T boundary dated at $65.5 \pm 0.3 \mathrm{Ma}$ should be located in between

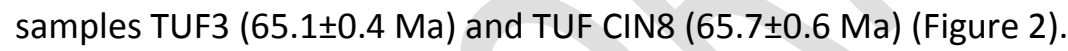

Three periods of with negative values in $\delta^{13} \mathrm{C}$ can be recognized in the Yacoraite Formation (Figure 2): at the base (system tract $1 a-T$ ), in the middle (primarily sequence 3 ) and at the top in the middle of sequence 4 (system tracts $4 a-R$ and $4 b-T$ ). These anomalies are recorded in proximal deposits with fluvial affinities, suggesting that part of the negative anomalies are related to $\mathrm{CO}_{2}$ leaching from soils. According to the age model established from zircon $\mathrm{U}-\mathrm{Pb}$ analyses, the negative anomaly in $\delta^{13} \mathrm{C}$ located in the middle part of the Yacoraite Formation suggests that the K-T boundary is very close to the base of sequence 3 (Figure 2). This is in line with the works of Sial et al. (2001) and Marquillas et al. (2007) based on bulk-rock carbonate isotope analyses $\left(\delta^{13} \mathrm{C}\right)$.

\subsection{Organic matter distribution}


Rock-Eval ${ }^{\circledast}$ results are presented in the supplementary materials and organized vertically along the synthetic sedimentary column in Figure 2 . The values show a large range $\left(\mathrm{TOC}_{0}, \mathrm{HI}\right)$ because the data of several measured sections are projected along the reference section (Figure 2). The evolution of the highest values for each time interval is especially described here because they represent the highest potential of the lacustrine system. In sequence 1 , there is very few occurrences of organicrich deposits (Figure 2). Few samples indicate $\mathrm{TOC}_{0}$ value higher than 2 wt.\% with average presentday hydrogen index (HI) of $629 \mathrm{mgHC} / \mathrm{gTOC}$. In sequence 2, the thickness and occurrence of organicrich deposits strongly increase in comparison to sequence 1 (Figure 2). $\mathrm{TOC}_{0}$ and $\mathrm{HI}$ values are in the same order of magnitude than during sequence $1 . \mathrm{HI}$ can locally reach $758 \mathrm{mgHC} / \mathrm{gTOC}$. The base of the sequence 3 is characterized by a sharp decrease in $\mathrm{TOC}_{0}$ and $\mathrm{HI}$ values (Figure 2). The high quality of organic matter (Type I) occurring during the deposition of sequences 1 and 2 was suddenly lacking in the lacustrine system (base of $3 \mathrm{a}-\mathrm{T}$ ). $\mathrm{HI}$ values recovered up to $800 \mathrm{mgHC} / \mathrm{gTOC}$ just on top of a transgressive surface (mid part of 3a-T, Figure 2), combine with a drastic increase in $\mathrm{TOC}_{0}$ values (up to 14.5 wt.\%). TOC $_{0}$ values then progressively decrease upward during sequence 3 . $\mathrm{HI}$ values kept at high values (Figure 2). Sequence $4 a$ is characterized by values similar to the ones of sequence 2 (TOC 0 ranging between 1 to $3 \mathrm{wt} . \%, \mathrm{HI}$ around $600 \mathrm{mgHC} / \mathrm{gTOC}$ ). Finally, sequence $4 \mathrm{~b}$ was characterized by lower TOC values with some brief pulse (up to $3.5 \mathrm{wt} . \%$ ) and $\mathrm{HI}$ ranging in between 200-250 $\mathrm{mgHC} / \mathrm{gTOC}$.

The pulse in $\mathrm{TOC}_{0}$ occurring in sequence 3 is also documented in the other sub-basins forming branches of the Salta rift Basin such as the Lomas de Olmedo and Tres Cruces to the NW and N respectively (Gomez Omil et al., 1989; Uliana et al., 1999).

\subsection{Dilution: insights from sedimentary budget}

To assess the dilution of organic matter, we characterized the lacustrine dynamic at basin scale following a source-to-sink approach. The mean accumulation rate for the carbonate-dominated margin setting is $52 \mathrm{~m} /$ Myr during the deposition of the Yacoraite Formation in the Alemania and 
Metán sub-basins. Accumulation rates are consistent with this mean value during the deposition of sequence 1 and part of sequence 2 (Figure 4). A pulse in accumulation rate (118-143 m/Myr) was recorded during the middle of the sequence $2(2 b-T$ and $2 b-R)$ followed up by a progressive decrease down to $23 \mathrm{~m} / \mathrm{Myr}(2 \mathrm{c}-\mathrm{R})$. Sequences 3 and 4 are then characterized by lower values ranging from 10-66 m/Myr with a mean at $29 \mathrm{~m} / \mathrm{Myr}$, that is about two time lower than during the deposition of sequences 1 and 2. A pulse in carbonate accumulation rate was recorded during sequence $4(4 a-T)$. Sequence 4 is characterized by higher values than sequence 3 , and resumed toward values occurring during the deposition of sequences 1 and 2 (Figure 4).

The mean carbonate accumulation rate for offshore-profundal depositional environments was 15 $\mathrm{m} /$ Myr with values ranging from 3 to $31 \mathrm{~m} /$ Myr in the Alemania and Metán sub-basins (Table 2). The trend identified using a source-to-sink approach are very similar to the trend derived from the MinC (Figure 4). The highest values (29-31 m/Myr) were recorded at the very base of the Yacoraite Formation (1a-T) and during sequence $2(2 \mathrm{c}-\mathrm{T})$ (Figure 4). Changes of $\mathrm{TOC}_{0}$ were recorded during deposition of sequence $3 a$ including $3 a-T$ and $3 a-R$ characterized by accumulation rates of 12 and 21 $\mathrm{m} / \mathrm{Myr}$ respectively. The progressive decrease in $\mathrm{TOC}_{0}$, from values between $8-15 \mathrm{wt} . \%$ to values between 3-6 wt.\%, could thus be interpreted as a dilution effect. Nevertheless, during the deposition of sequence $3 \mathrm{~b}$, accumulation rates were very low (9-15 m/Myr) and $\mathrm{TOC}_{0}$ only ranged between 0.51.5 wt.\% (Figure 1), suggesting that additional factors controlled the organic matter accumulation.

The mean sediment supply (Qs) is $363 \mathrm{~km}^{3} /$ Myr during the deposition of the Yacoraite Formation in the Alemania and Metán sub-basins (Table 2). During sequence 1, the mean sediment supply was fairly lower, ca. $134 \mathrm{~km}^{3} /$ Myr. Qs progressively increased during sequence 2 to reach its maximum (1440 $\mathrm{km}^{3} /$ Myr, 2c-T; Figure 4). Qs rapidly decreased during the beginning of sequence 3 (3a-T and 3a-R) to reach lower values (mean ca. $118 \mathrm{~km}^{3} / \mathrm{Myr}$ ) that lasted till the end of sequence 3 and sequence 4 (Figure 4). The pulse in Qs (2c-T) is coeval with a rapid decrease in carbonate production in proximal settings, and a pulse in carbonate production in distal settings. This suggests that high Qs 
could have had increased water turbidity, inducing a shutdown of the carbonate production in proximal settings, just prior to the K-T boundary (Figure 4).

Sequence $3 b(3 b-T, 3 b-R)$ was characterized by low Qs values following the rapid Qs decrease initiated at the base of sequence 3 (Figure 4). This period of time (3b-T, 3b-R) has also recorded a pulse in Ti/Al and $\mathrm{K} / \mathrm{Al}$, as well as very low value in both $\mathrm{CIA}$ and $\mathrm{ClA}$ (Figure 4). Pulses in Ti/Al are commonly associated to aeolian dust delivery, suggesting high aridity (Pye, 1987). Pulses in K/Al could be related to surge flood event from the river system (Chester et al., 1977). Low value in both $\mathrm{CIA}$ and $\mathrm{CIA}^{*}$ are primarily associated to the lack of chemical weathering processes in the catchments. The combination of these three proxies points at evidences for low vegetation cover and purely mechanical erosive processes in the catchments. This brief event marks the turn over from previous high sediment supply setting to "normal" sediment delivery into the lake.

\subsection{Organic matter production - Paleoproductivity}

There are only few data to properly characterize the paleoproductivity dynamic for sequence 1 (Figure 5), because facies are too proximal and our study was more dedicated to the lacustrine dynamic occurring just before, during and after the K-T crisis. During the deposition of sequence 2, there were very few pulses of paleoproductivity (Figure 5). The most evident pulse is coeval with the MFS2 (base of 2a-R). Starting at the base of sequence 3 and pursuing during sequence 4 , the occurrence of high paleoproductivity events strongly increased (Figure 5). A first cluster of high productivity events occurred during sequence $3(3 a-T)$, a second one around the MFS3 (base of $3 b-R$ ), and finally several isolated events that became very scarce during sequence 4 (Figure 5). There is a good match between paleo-bathymetry and paleoproductivity (e.g. MFS2, MFS3), nevertheless the relationship is not straightforward. For example, MFS3a (between 3a-T and 3a-R) was not characterized by a significant increase of paleoproductivity. Furthermore, system tract 3a-T was characterized by numerous events, even though it was not characterized by the highest paleobathymetry (Figure 5). 


\subsection{Organic matter destruction - Redox conditions}

In this study, we selected the widely used $\mathrm{Ni} / \mathrm{Co}, \mathrm{U} / \mathrm{Th}, \mathrm{V} / \mathrm{Cr}$ and $\mathrm{V} /(\mathrm{V}+\mathrm{Ni})$ ratios to efficiently discriminate the redox conditions (Hatch and Leventhal, 1992; Jones and Manning, 1994). Table 3 summarizes the relationship between trace element ratios and redox domains. In Figure 6, the squares indicate the measured data. Period of potential euxinic-anoxic conditions were highlighted for each ratios by colored lines (Figure 6).

Out of the four selected criteria, Ni/Co ratio suggests numerous periods of anoxia (Figure 6). Number and frequency of anoxic periods strongly increase during sequences 3 and 4. U/Th ratio corroborates these results, but with less events of anoxia (Figure 6). The potential occurrence of anoxic events deduced from the $\mathrm{V} / \mathrm{Cr}$ ratio are much less than using the two previous ratios (Figure 6). For example, only one event was recorded during the sequence 2 (2c- $\mathrm{T}$ ) based on the $\mathrm{V} / \mathrm{Cr}$ ratio (Figure 6). $\mathrm{V} /(\mathrm{V}+\mathrm{Ni})$ is the most stringent criterion to document anoxia, i.e. the number of potential event are much lower using $\mathrm{V} /(\mathrm{V}+\mathrm{Ni})$ than using all the previous ratio (Figure 6$)$. In this work, we propose that the main events of anoxia could be highlighted when respecting the criteria for the four ratios. Several events are documented during the MFS3a (transition between 3a-T to 3a-R). Another cluster of periods of anoxia was recorded during the deposition of sequence 4a (Figure 6). Few events occurred during the deposition of $4 \mathrm{~b}-\mathrm{R}$.

During the deposition of sequence 3, periods of anoxia were not coeval with pulses in paleoproductivity (out-of-phase dynamic). It suggests that redox conditions were not controlled by paleoproductivity during this time interval. During the deposition of sequence 4, periods of anoxia were coeval with pulses in paleoproductivity (in-phase dynamic). It suggests that paleoproductivity could have controlled the redox conditions on the lake floor during this time interval (Sequence 4).

\section{Discussion}

\subsection{Age model and K-T identification}


The surfaces at the base and top of the Yacoraite Formation are the less constrained time lines in our work. The base is constrained by reworked ash layers and could therefore be older. Based on carbonate accumulation rates and average sediment fluxes during the deposition of sequence 1 ( $55 \mathrm{~m} /$ Myr and $134 \mathrm{~km}^{3} /$ Myr respectively), the age of the base could possibly be extrapolated to 69.4 to 69. $7 \mathrm{Ma}$. It lies within the error bar of $69.1 \pm 0.7 \mathrm{Ma}$ (Figure 2 ). This age is consistent with volcanic deposits at the base of the Yacoraite Formation dated to ca. $70 \mathrm{Ma}$ (Boll et al., 1989) in the Lomas de Olmedo sub-basin. Following the same rational, the top of the Yacoraite Formation also lies within the error bar of $64.0 \pm 0.5 \mathrm{Ma}$ (Figure 2). As no sedimentological or geochemical data suggest a major change of the carbonate accumulation rates and average sediment fluxes in sequences 1 and 4 , the ages of base and top surfaces are the most reasonable up to date interpretation.

According to bulk-rock carbonate isotope analyses $\left(\delta^{13} \mathrm{C}\right)$, Sial et al. (2001) and Marquillas et al. (2007) initially proposed that the K-T boundary occurred at the base of sequence 3. Later, Marquillas

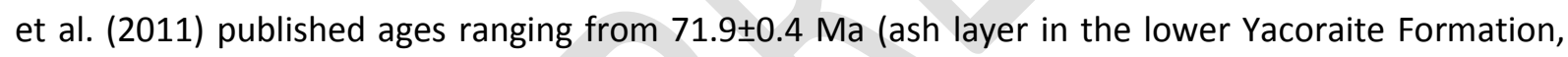
sequence 1) to $68.4 \pm 0.7 \mathrm{Ma}$ (ash layer of the upper Yacoraite Formation, sequence 3 ). This upper ash layer (same outcrop, same layer) corresponds to our TUF3 sample. TUF3 is dated here to $65.1 \pm 0.4$ Ma. It was then critical to check these ages because the results of Marquillas et al. (2011) would have imply a shift of the K-T boundary in the overlying series. We duplicated the samples and analyses that were very self-consistent (Table 1). TUF1 is dated here to $66.2 \pm 0.5 \mathrm{Ma}$, and TUF1 bis (same layer in the same outcrop as TUF1) to $66.5 \pm 0.4 \mathrm{Ma}$. There is clearly a shift ( 3 to $4 \mathrm{Ma}$ ) between our results and those of Marquillas et al. (2011). We suspect a problem of representative zircon grain analysis in the work of Marquillas et al. (2011) as they do not indicate the number of analyzed zircons, neither the procedure to extract the inherited grains resulting from previous volcanic events, and then to properly measure the age of the volcanic event contemporaneous with the Yacoraite Formation deposition (Paquette et al., 2015). In our case, out of twelve samples (2 kg each), only eight samples provided enough zircon grains ( $>8$ grains per sample) to carry out consistent analyses (Table 1 ). 
The exact location of the surface recording the K-T is nevertheless not certain. Indeed, a very dense sampling across the sequence boundary 3 (SB3) did not provide information to pick precisely the K-T by highlighting a trace metal anomaly. Negative anomaly of the carbonate $\delta^{13} \mathrm{C}$ values was initiated during the deposition of system tract $2 \mathrm{C}-\mathrm{R}$, just below $\mathrm{SB} 3$, very close by to an ash layer providing an absolute age at ca. $64.5 \pm 1 \mathrm{Ma}$ (Figure 2). This negative anomaly could reach up to $-5.0 \%$ (Figure 2). Two main phenomenon could have induced such a major negative anomaly: (i) an increase in water supply from the catchment, or (ii) an increase in isotopically light carbon fluxes into the basin. Kump (1991) showed that a small negative gradient in the $\delta^{13} \mathrm{C}$ preserved in carbonate as much as $0.1 \%$ could be produced by water supply from the catchments $\left(\delta^{13} \mathrm{C}=-5.0 \%\right)$ to a homogenized K-T ocean on a short time scale. This offset is considerably less than observed in this study (Figure 2) and therefore is not considered sufficient here. An additional input of isotopically light carbon to the lake was necessary to generate the observed reversed pattern. $\mathrm{CIA}$ and $\mathrm{CIA}^{*}$ values $(>60)$ during sequence 2c support a potential weathering in the catchments (Figure 4). Soil degradation during the propagation of sequence boundary 3 , and resulting $\mathrm{CO}_{2}$ fluxes to the lake could thus be a good candidate to explain such an offset in $\delta^{13} \mathrm{C}$. All these evidences point out toward a K-T boundary in the vicinity of sequence boundary 3 .

\subsection{The K-T boundary: a progressive climate change?}

Sediment supply dynamic can be interpreted either in terms of climate or tectonic change (e.g. Bonnet and Crave 2003, Rohais et al., 2012). The trends and amplitudes of sediment supply changes are then crucial for qualifying the nature of the forcing mechanism, i.e. whether a pulse has a tectonic or climatic origin (Rohais et al., 2012). The sediment supply during the deposition of the Yacoraite Formation shows a growth phase and then a decay phase to return to values close to those before the change (Figure 4, Figure 7). This trend typically accompanies climate changes (Bonnet and Crave 2003, Rohais et al., 2012), with either a change in vegetation cover or in erosional processes in the catchment areas. Instead, a change in tectonic setting would have implied a definitive increase, 
or decrease in sediment supply, toward a new and stable mean value. The lack of major tectonic change during the deposition of the Yacoraite Formation is also supported by the results based on backstripped wells using subsurface data indicating no major shift in the subsidence (Stark , 2011). This sediment supply deduced climate change initiated well before the K-T crisis, around the deposition of sequence 2a-R (ca. $65.7 \pm 0.6 \mathrm{Ma}$ ) and lasted to ca. $65.1 \pm 0.5 \mathrm{Ma}$ (Figure 4, Figure 7). As multiple impact events just prior to the K-T boundary have been documented (Chatterjee, 1997) as well as potential influence of the Deccan traps (Duncan and Pyle, 1988), we could speculate that the climate change recorded in the Yacoraite Formation by a sediment supply (Qs) pulse could be related to these global events. Whatever the triggering mechanism for climate change at the K-T boundary, our study supports a clear record of climate change in the lacustrine deposits of the Yacoraite Formation that lasted for ca. 0.6 Myr (initiated ca. 0.2 Myr before the K-T and ended ca. 0.4 Myr after). This climate change was rapid and drastic at geological scale. Indeed, the sediment supply became up to ten times higher than the one before the crisis (Figure 4). Assuming a catchment area of ca. $50 \mathrm{~km}$-long surrounding the lake, we could estimate 0.5 to $2.5 \mathrm{~m}$ of erosion on the entire catchment area during each system tract (fourth order scale). Soil deposits should have been fully eroded and exported into the lake in such scenario, at each time step. The trends of $\mathrm{CIA}$ and $\mathrm{Cl} \mathrm{A}^{*}$ indicate that just after the K-T crisis, low chemical weathering processes occurred (just on top of SB3). Mechanical erosion was dominant just after the K-T crisis. It is coeval with poor quality of organic matter interval (low $\mathrm{TOC}_{0}$ ) (Figure 7). High values of $\mathrm{CIA}$ and $\mathrm{ClA}^{*}$ indicate resuming weathering processes and potential soil occurrences in the catchment during the deposition of the top of sequence 3a-T (Figure 4).

\subsection{Triggers for organic carbon enrichment in lacustrine system}

The combination of extremely high hydrogen indices ( $>600 \mathrm{mgHC} / \mathrm{gTOC})$ and low oxygen indices $(<50$ mgCO2/gTOC) is characteristic of Type I kerogen, mainly derived from algae in lacustrine settings. Previous studies have also demonstrated that the Yacoraite Formation shows a clear dominance of 
Type I lacustrine organic matter and represents a series from immature to overmature source rocks (e.g Romero-Sarmiento et al., 2019). This character is very consistent all along the Yacoraite Fm. section (Figures 2 and 7), indicating rich accumulations of organic matter dominated by algal component. There are nevertheless two periods of time characterized by lower hydrogen indices (Figure 2). The upper part (sequence 4b), as well as the deposits related to SB3 are dominated by lower $\mathrm{TOC}_{0}$ and $\mathrm{HI}$ values suggesting a progressive increase of terrestrial organic matter input (Figure 2). The Yacoraite Formation best meets criteria for the fluctuating profundal, balanced-filled model of Carroll and Bohacs $(1999,2001)$ and Bohacs et al. (2000) based on lithologies, sedimentary structures, stratal patterns and organic matter type. Nevertheless, such models fail to capture the organic carbon enrichment both at the scale of the deposition of the Yacoraite Formation (ca. 5 Myr) and at higher resolution.

Models for lacustrine source rock deposition commonly relate the quality of source rocks to the balance between creation of accommodation space in a lake basin and the water and sediment supplies to the basin (Carroll and Bohacs, 1999, 2001; Bohacs et al., 2000), or rather to processes in the surrounding catchments, namely, weathering, carbon cycling, and soil development (Harris, 2000; Harris et al., 2004; 2005).

In the Yacoraite Formation, the periods of carbon organic enrichment in comparison to the background organic accumulation (black arrows on Figure 7, four main events) are coevals with high $\mathrm{ClA}^{*}$ values. High $\mathrm{CIA}$ * values could be interpreted as evidence for high weathering resulting in intermediate profile with thick soils (Harris et al., 2004). The concentration of nitrate in lake water is strongly influenced by soil processes (Meyers, 1997); therefore, with increased efficiency in the cycling of plant matter in soils to dissolved compounds in ground and surface water, the delivery of nitrate to the rift lake should have also increased (Harris et al., 2004). This could induce an increase in paleoproductivity. Surprisingly, three out of the four main events do not coincide together with 
paleoproductivity pulses, neither anoxic event (Figure 7). Mechanical erosion interpreted from low $\mathrm{CIA}^{*}$ values should be invoked to transfer nutrient into the lake and then control paleoproductivity.

As the anoxic pulses are also often out of phase with the paleoproductivity pulses, we suggest that the paleoproductivity was not triggering the redox conditions. Conversely, water column stratification and pycnocline evolution should be invoked in relationship with lake water chemistry, temperature or salinity .

The four main periods of carbon organic enrichment are not neither characterized by high lake level, nor very low accumulation rates (black arrows in Figure 7). Low sedimentation rates in the distal setting do not completely account for the enrichment in organic carbon, nor do they account for the shift in type of organic matter (low values to lack of organic matter on the K-T boundary, and lower values during sequence 4). Dilution by clastic or carbonate sediment was nevertheless potentially a contributing factor to reach lower $\mathrm{TOC}_{0}$ value during sequence 3 (Figure 7). Dilution should thus be seen as a modulating factor instead of major triggering parameters in the case of the Yacoraite Formation.

The highest quality organic matter source rock in the Yacoraite Formation occurred during the deposition of sequence 3, after the K-T boundary as highlighted by a large black arrow in Figure 7 . This period is characterized by (i) a rapid increase of the lake level toward the highest level recorded by the lake, (ii) low to medium carbonate accumulation rate in the distal setting, (iii) decreasing sediment supply starting from previous very high value, (iv) potential weathering in the catchment with intermediate profile and thicker soils development, (v) numerous pulses in paleoproductivity and no evidence for anoxia, at least at the beginning of the accumulation (Figure 7). Our results contradict the conceptual models proposing that the best source rocks occur during development of the deepest rift lakes during (Lambiase, 1990; Katz, 1995), neither fully satisfy the most recent models of Carroll and Bohacs (1999, 2001), Bohacs et al. (2000), Harris (2000) and Harris et al. (2004; 
2005). Instead, a dynamically linked and evolving system should be proposed, especially because we are going through the $\mathrm{K}-\mathrm{T}$ climate change in our example.

\subsection{The Yacoraite Formation: a biological pump across the K-T}

Before the K-T boundary, $\mathrm{ClA}^{*}$ indicate that the lake was dominantly characterized by weatheringlimited soil profile (dominant mechanical erosion, Figure 7) triggering a low to moderate flux of $\mathrm{CO}_{2}$ and/or nitrate to lake, thus limiting organic productivity in surface waters (Harris et al., 2004). Conversely, just after the K-T boundary, $\mathrm{ClA}^{*}$ indicate that the lake was primarily characterized by intermediate soil profile leading to slower removal of weathered material (Figure 7). Vegetation was more efficiently incorporated into soils inducing high $\mathrm{CO}_{2}$ and/or nitrate flux to lake (Harris et al., 2004). As a results, intense organic paleoproductivity (algal growth) occurred in the lake and could have reduced oxygen levels in water column during sinking of organic matter.

Our results support a ca. 1 Myr long model of evolution of the lake dynamics and its organic matter distribution across the K-T boundary in six major stages (Figure 7), as follow:

(1) Stage 1 corresponds to the reference level showing a good quality source rock interval but low enrichment of organic matter (HI 400-600 mgHC/gTOC, TOC $0.5-1.5$ wt.\%). The carbon organic enrichment was entirely driven by erosion processes in the catchments i.e. the supply of nutrients primarily occurred during intermediate soil development as suggested by $\mathrm{CIA}^{*}$ (Figure 7).

(2) Around 0.3 Myr before the K-T (beginning of stage 2, Figure 7), a pulse of sediment supply was initiated, probably in response to a change in vegetation cover inducing a change in erosion process. The accumulation rates of marginal carbonates were not significantly affected, but accumulation rate in the distal part increased (Figure 4, Figure 7). HI values already suggest very good quality organic matter intervals (600-800 mgHC/gTOC). However TOC ${ }_{0}$ values remain moderate (1-2 wt.\%) and organic carbon enrichment follow a similar dynamic as during stage 1 (Figure 7). 
(3) Just before the K-T crisis (Stage 3), a ClA* pulse suggests dominant erosion processes by weathering (thicker soil establishment) and an important vegetation cover (Figure 7). This period was also characterized by an increase in $\mathrm{TOC}_{0}$ content (2-3 wt.\%) even if sediment supply and accumulation rates were relatively higher (Figure 7).

(4) The K-T boundary was marked by a major drop in the accumulation rates of carbonates, already initiated just before the crisis when the sediment supply was at its maximum (Figure 7). We interpret this evolution as an increase in water turbidity in relation to high sediment supply, and a limitation of carbonate production rates. The K-T boundary was characterized by a major drop of $\delta^{13} \mathrm{C}$ (carbonate), $\mathrm{HI}$ and $\mathrm{TOC}_{0}$, nevertheless some proxies still support coeval paleoproductivity pulses (Figure 7). In this case, the carbonate $\delta^{13} \mathrm{C}$ negative anomaly not necessarily records a shut-down of paleoproductivity. $\mathrm{ClA}^{*}$ suggest a predominance of mechanical erosion processes just after the $\mathrm{K}-\mathrm{T}$, following a period of time with intermediate soil profile development. $\mathrm{High} \mathrm{CO}_{2}$ and/or nitrate flux to lake could have occurred by coeval high sediment supply and lowering lake level could have prevent algal growth, resulting finally into a lack of organic matter accumulation.

(5) Soil and vegetation cover then recovered, along with the major pulse of TOC at the transition from stage 4 to 5 (Figure 7). Sediment supply was still high, and marginal carbonate accumulation rates remained low. Surprisingly, the major $\mathrm{TOC}_{0}$ pulse does not coincide perfectly with a period of high lake paleoproductivity, and rather occurs just after or in between pulses of paleoproductivity (Figure 7). Oxidation of sinking organic matter could then have reduced oxygen level in water column as suggested by the following pulse of anoxic conditions (Figure 7). The sediment supply then rapidly decreased during stage 5. Meanwhile the carbonate accumulation rates in the distal part increased, suggesting an increase of the paleoproductivity in the lake depocenter. It is corroborated by the paleoproductivity proxies (Figure 7). HI values still suggest a good quality organic matter, however TOC content decreases gradually. This stage 5 ended with a pulse of aridity underlined by the Ti/Al ratio (Figure 4), which is also corroborated by a major drop in $\mathrm{CIA}^{*}$ (Figure 7). It indicates a 
weathering-limited soil profile probably in relation with a complete destruction of the vegetation cover.

(6) Finally, stage 6 was very similar to stage 1 as recorded by the sediment supply, accumulation rates, $\mathrm{ClA}$ and $\mathrm{ClA}^{*}, \mathrm{TOC}_{0}$ and $\mathrm{HI}$ values (Figure 7). This suggests that the lacustrine system resumed to its initial dynamic (Figure 7). The lacustrine system nevertheless show for the very first time coeval pulses of paleoproductivity and anoxic pulses (Figure 7), supporting that after the K-T boundary, intermediate soil profile and resulting soil $\mathrm{CO} 2$ flux was the dominant setting. Stage 6 could be considered as the end-member for intermediate soil profile triggering lacustrine system, while stage 1 could be considered as the end-member for weathering-limited soil profile.

\section{Conclusions}

The Yacoraite Formation can be considered as a world-class example to illustrate how the K-T crisis was recorded in lacustrine sediments. The record modalities of the K-T are presented based on an integrated approach coupling dating, sedimentary budget, geochemical and isotopic analyzes in a lacustrine system. The obtained results can be summarized as follow:

(1) The Yacoraite Formation was deposited between $69.1 \pm 0.7$ to ca. $64.0 \pm 0.5 \mathrm{Ma}$ using ashes dating on U-Pb zircon analysis, a period of time including the K-T boundary.

(2) The Yacoraite Formation recorded a major climate change with a specific response in term of catchment dynamic, erosion processes, carbonate accumulation trends, lacustrine dynamic and organic matter distribution and quality. The K-T boundary was the striking point of a climate change initiated ca. 0.3 Myr before. The K-T induced a major shut down in weathering processes in the catchments coeval with poor quality organic matter (very low TOC and $\mathrm{HI}$ ). The brief and intense event is superimposed onto two opposite dominant erosional processes changing across the $\mathrm{K}-\mathrm{T}$ boundary; mechanical erosion and weatheringlimited soil profile versus weathering and intermediate soil profile development, respectively before and after the K-T. 
(3) The carbonate $\delta^{13} \mathrm{C}$ negative anomaly recording the K-T was not necessarily coeval with a shut-down of paleoproductivity. Conversely, the K-T boundary was rapidly followed by a major pulse in paleoproductivity, itself followed by a major pulse in TOC (10-15 wt.\%) and anoxia conditions. It suggest that the triggering mechanism for organic carbon enrichment were successive such as in a biological pump or cycle, with (i) the emplacement of soils and resulting $\mathrm{CO}_{2}$ and/or nitrate flux, (ii) intense organic paleoproductivity (algal growth), (iii) organic matter accumulation and preservation coeval with strong anoxia. In that sense, nutrient availability and paleoproductivity, and thus climate was the triggering mechanism for lacustrine organic enrichment across the K-T.

(4) In ca. 0.2 Myr the lacustrine dynamic resume to its initial setting, just prior to the preluding climate change. The 1 myr-long documented behavior is also superimposed by higher frequency cycles (20-100 kyr) sharing similar pattern, especially in dominant intermediate soil profile setting.

\section{Acknowledgments}

Part of this work was supported by companies in the frame of the Joint Industrial Project COMPAS (2012-2015) leaded by IFP Energies Nouvelles: BHP Billiton, BP, Chevron, Cobalt Inc., Ecopetrol, ENI, ExxonMobil, GalpEnergia, Total, MaerskOil, Petrobras, Repsol, YPF S.A.. We would like to thank Claudia Galli for its help and support during the initiation of our work in the Salta-Jujuy provinces. We want to acknowledge Mario Schiuma, Maria-Elena Kusiak, Juan-Pablo Lovecchio and Ricardo Calegari for their continuous support and fruitful discussions for the last 10 years. We also really appreciate the support of José Salfity during several field excursion. One anonymous reviewer, as well as the editor Ralf Littke provided constructive comments on an earlier version which greatly helped to improve the manuscript. 
Figure 1: Location and thickness map of the Yacoraite Formation in the Alemania and Metán subbasins. Red dot indicates the location of the Cabra corral section (reference section of Figure 2). Black dots without label were used as control point to build the thickness map. Regional cross sections (Transects A and B) and measured sections (black dots with label) are presented in Figure 3. Coordinate reference systems: Campo Inchauspe / Argentina 3 (Transverse Mercator -90, -66).

Figure 2: Reference section for the Yacoraite Fm. in the Alemania and Metán sub-basins (Cabra corral area) with sequence interpretation (Red triangle for prograding trend, blue triangle for retrograding trend), system tracts, age model using zircon dating, lake level interpretation, TOC, $\mathrm{HI}$ and $\delta^{13} \mathrm{C}$ (carbonate) values. Main surfaces: sequence boundary in red (SB), transgressive surface in green (TS) and maximum flooding surface in blue (MFS). Lithology: blue stands for carbonate-dominated deposits, light blue for fine-grained mixed deposits, yellow for siliciclastic-dominated deposits. Sequence, system tracts and lake level interpretations take benefit of previous in-house detailed stratigraphic results from the Joint Industrial Project COMPAS led by IFPEN from 2012 to 2015. The present-day TOC values are indicated in black square whereas the calculated original $\mathrm{TOC}_{0}$ in grey. The hatched area stands for the K-T boundary. See Figure 1 for location.

Figure 3: Regional cross sections illustrating the stratigraphic architecture of the Yacoraite Fm. in the Alemania and Metán sub-basins. The reference section is highlighted with its gamma ray log. See Figure 1 for location. Correlations are simplified from in-house detailed stratigraphic results from the Joint Industrial Project COMPAS led by IFPEN from 2012 to 2015.

Figure 4 : Results from the sedimentary budget analysis together with detrital proxies based on elemental analyses in the Alemania and Metán sub-basins. Accumulation rates including carbonate accumulation rates for marginal and deep settings, sediment supply with their error bars. Paleoclimate and paleoenvironmental proxies including, $\mathrm{Ti} / \mathrm{Al}$ and $\mathrm{K} / \mathrm{Al}$ ratios, and $\mathrm{CIA}$ and $\mathrm{CIA}$ * indexes. See text for further explanation about their computations and interpretations. 
Figure 5: Paleoproductivity proxies for the Yacoraite $\mathrm{Fm}$. including $\mathrm{P} / \mathrm{Ti}, \mathrm{Ba} / \mathrm{Al}, \mathrm{Ni} / \mathrm{Al}$ and $\mathrm{Cu} / \mathrm{Al}$ ratios. Favorable conditions are highlighted with purple lines when at least two ratios support high paleoproductivity setting.

Figure 6 : Redox proxies for the Yacoraite $\mathrm{Fm}$. based on $\mathrm{Ni} / \mathrm{Co}, \mathrm{U} / \mathrm{Th}, \mathrm{V} / \mathrm{Cr}$ and $\mathrm{V} /(\mathrm{V}+\mathrm{Ni})$ ratios. Favorable anoxic conditions are highlighted for each ratio with orange lines. Orange dots correspond to the dataset. See Table 3 for explanation about the cut-off.

Figure 7 : Synthesis of the Yacoraite Formation lacustrine sediments dynamic across the K-T boundary in the Alemania and Metán sub-basins. New age model based on zircon analyses is proposed to localize the K-T boundary (hatched area). Period of time of highest lake level are highlighted by blue rectangles. Organic carbon enrichment is documented after both the calculated original $\mathrm{TOC}_{0}$ and the $\mathrm{HI}$ values. Periods of increase in organic carbon enrichment are illustrated by black arrows. Dilution is interpreted after sediment supply ( $Q$ s, in yellow), carbonate accumulation rate (distal, in blue), together with $\mathrm{ClA}^{*}$ to discuss the weathering processes and resulting soil profiles. Dominant setting are highlighted by green rectangle and brief pulses by green arrows. The six numbers in the sediment supply column correspond to the main stages discussed in the text. Paleoproductivity and anoxic pulses are highlighted according to elemental analyses. 
Table 1: U-Pb ash dating on zircons in the Yacoraite Formation in the Alemania and Metán subbasins. MSWD: Mean Standard Weighed Deviation. N: Number of measurements on isolated zircons.

Table 2: Results of the sedimentary budget analysis in the Alemania and Metán sub-basins. Accumulation rates including carbonate accumulation rates for marginal and deep settings, sediment supply with their error bars are shown in the frame of our age model.

Table 3: Cut-off and boundaries used to identify the redox conditions based on selected element ratio in Figure 6. 


\section{REFERENCES}

Alonso, R.N., and Marquillas, R.A., 1986. Nueva localidad con huellas de dinosaurios y primer hallazgo de huellas de aves en la Formacion Yacoraite (Maastrichtiano) del Norte Argentino. Actas 4th Congr Arg Paleont Bioestrat 2:33-41

Alvarez, L.W., Alvarez, W., Asaro, F., Michel, H.V., 1980. Extraterrestrial cause for the CretaceousTertiary extinction. Science. 208 (4448): 1095-1108. Bibcode:1980Sci...208.1095A. doi:10.1126/science.208.4448.1095.

Behar, F., Beaumont, V. De B., Penteado, H.L., 2001. Rock-Eval 6 technology: performances and developments. Oil Gas Sci. Technol. 56, 111e134. http://dx.doi.org/10.2516/ogst:2001013.

Bohacs, K.M., Carroll, A.R., Mankiewicz, P.J., Miskell-gerhardt, K.J., Schwalbach, J.O.N.R., Wegner, M.B., Simo, J.A.T., 2005. Production, destruction, and dilution-the many paths to source-rock development. In: Harris, N.B. (Ed.), The Deposition of Organic-carbon-rich Sediments: Models, Mechanisms and Consequences. Special Publications of SEPM, pp. 61-101.

Bohacs, K.M., Carroll, A.R., Neal, J.E., Mankiewicz, P.J., 2000. Lake-basin type, source potential, and hydrocarbon character: An integrated sequence-stratigraphic-geochemical framework, in E. H. Gierlowski-Kordesch and K. R. Kelts, eds., Lake basins through space and time: AAPG Studies in Geology 46, p. 3-34.

Boll A., R. Gómez Omil, R. Hernández, 1989. Síntesis Estratigráfica del Grupo Salta. Informe inédito YPF, Buenos Aires.

Bonnet, S., and Crave, A., 2003. Landscape response to climate change: Insights from experimental modelling and implications for tectonic versus climatic uplift of topography, Geology, 31 (2), 123-12. 
Brinkhuis, H. and Zachariasse, W. J., 1988. Dinoflagellate cysts, sea level changes and planktonic foraminifers across the Cretaceous-Tertiary boundary at El Haria, northwest Tunisia, Mar. Micropaleontol., 13, 153-191.

Brinkhuis, H., Bujak, J.P., Smit, J., Versteegh, G.J.M., Visscher, H., 1998. Dinoflagellate-based sea surface temperature reconstructions across the Cretaceous-Tertiary boundary, Palaeogeogr. Palaeoclimatol. Palaeoecol., 141, 67-83.

Burnham, A. K., 1989. On the validity of the pristane formation index: Geochimica Cosmochimica Acta, v. 53, p. $1693-1697$.

Calvert, S.E., and Pedersen, T.F., 1993. Geochemistry of recent oxic and anoxic marine sediments: Implications for the geological record. Marine Geology 113, 67-88. DOI 10.1016/00253227(93)90150-T

Carroll, A.R., and Bohacs, K.M., 1999. Stratigraphic classification of ancient lakes: Balancing tectonic and climatic controls: Geology, v. 27, p. 99-102.

Carroll, A.R., and Bohacs, K.M., 2001. Lake-type controls on petroleum source rock potential in non marine basins: American Association of Petroleum Geologists, Bulletin, v. 85, p. 1033-1053.

Claeys P., Kiessling W., Alvarez, W., 2002. Distribution of Chicxulub ejecta at the Cretaceous-Tertiary boundary. In Catastrophic Events and Mass Extinctions: Impacts and Beyond (eds. C. Koeberl and K. G. McLeod). Geol. Soc. Am. Spec. Paper 356, 55-68.

Chatterjee, S., 1997. in Proceedings of the 30th International Geological Congress, eds. Nang, H., Branagan, D. F., Ouyang, Z. \& Wang, X. (Geological) Congress, International Science Publishers, The Netherlands), Vol. 26, pp. 31-54. 
Chester, R., Baxter, G.B., Behairy, A.K.A., Connor, K., Cross, D., Elderfield, H., Padgham, R.C., 1977. Soil-sized eolian dusts from the lower troposphere of the eastern Mediterranean Sea. Marine Geology 24, 201-217. DOI 10.1016/0025-3227(77)90028-7

Cohen, K.M., Finney, S.C., Gibbard, P.L. and Fan, 824 J-X. 2013 updated. The ICS International $\begin{array}{lllll}\text { Chronostratigraphic } \quad \text { Chart; } & \text { Episodes } & \text { 199-204, } & \text { URL }\end{array}$ <http://www.stratigraphy.org/ICSchart/ChronostratChart2015-01.pdf> [August 2015].

Crombez, V., Baudin, F., Rohais, S., Riquier, L., Euzen, T., Pauthier, S., et al. 2016. Basin scale distribution of organic matter in marine fine-grained sedimentary rocks: Insight from sequence stratigraphy and multi-proxies analysis in the Montney and Doig formations. Marine and Petroleum Geology 83: 382-401. DOI: 10.1016/j.marpetgeo.2016.10.013.

Cushing, D.H., and Walsh, J.J., eds., 1976. The Ecology of the Deas: Philadelphia, W.B. Saunders Company, $467 \mathrm{p}$.

Deschamps R, Doligez B, Schmitz J, Joseph P, Rohais S, Pellerin M, Jones R, 2017. De la reconstitution numérique 3D d'affleurements au modèle de réservoir : une approche intégrée. Géologues, n¹93 juin 2017 - ISSN 0016.7916, p. 68-71

Duncan, RA; Pyle, DG (1988). "Rapid eruption of the Deccan flood basalts at the Cretaceous/Tertiary boundary". Nature. 333 (6176): 841-843.

Espitalié, J., Deroo, G., Marquis, F., 1986. La pyrolyse Rock-Eval et ses applications. Première partie. Oil Gas Sci. Technol. 40, 563e579. http://dx.doi.org/10.2516/ogst:1985035 Gómez Omil, R. y A. Boll, 1999, Sistema petrolero de la Cuenca Cretácica del Noroeste Argentino, IV Congreso de Exploración y Desarrollo de Hidrocarburos, IAPG, Actas I, p. 101-126, Buenos Aires. 
Gomez Omil, R.J., Boll, A., Hernandez, R.M., 1989. Cuenca cretacicoterciaria del Noroeste argentino (Grupo Salta). In: Chebli GA, Spalletti LA (eds) Cuencas Sedimentarias Argentinas. Universidad Nacional de Tucuman, Serie de Correlacion Geologica 6:43-64.

Harris, N B., 2000. Evolution of the Congo rift basin, west Africa: An inorganic geochemical record in lacustrine shales: Basin Research, v. 12, p. 425-445.

Harris, N.B., Freeman, K.H., Pancost, R.D., White, T.S., Mitchell, G.D., 2004. The character and origin of lacustrine source rocks in the Lower Cretaceous synrift section, Congo Basin, west Africa. AAPG Bull. 88, 1163-1184.

Harris, N. B., Freeman, K. H., Pancost, R. D., White, T. S., Mitchell, G. D., Bate, R. H., 2005. Patterns of Organic Carbon Enrichment in a Lacustrine Source Rock in Relation to Paleo-Lake Level, Congo Basin, West Africa. In N. B. Harris (Ed.), The Deposition of Organic Carbon-Rich Sediments - Models, Mechanisms and Consequences. SEPM Special Publication (Vol. 82). SEPM. pp. 103-123. ISBN 1$56576-110-3$

Hatch, J.R., Leventhal, J.S. 1992. Relationship between inferred redox potential of the depositional environment and geochemistry of the Upper Pennsylvanian (Missourian) stark shale member of the Dennis Limestone, Wabaunsee County, Kansas, USA. Chem Geol 99:65-82

Hsu, K.J., and McKenzie, J.A., 1985. A "Strangelove" ocean in the earliest Tertiary. In: Sundquist, E.T., and Broecker, W.S., eds., 20 The carbon cycle and atmospheric C02: Natural variations Archean to present: Washington, D.C., American Geophysical Union, p. 487-492.

Hurai, V., Paquette, J.L., Huraiová, M., Konecný, P., 2010. U-Th-Pb geochronology of zircon and monazite from syenite and pincinite xenoliths in Pliocene alkali basalts of the intra-Carpathian backarc basin. Journal of Volcanology and Geothermal Research 198, 275-287. 
Jarvie, D.M., Hill, R.J., Ruble, T.E., Pollastro, R.M., 2007. Unconventional shale-gas systems: the Mississippian Barnett Shale of north-central Texas as one model for thermogenic shale-gas assessment. AAPG Bulletin 91, 475e499.

Jones, B.A., and Manning, D.A.C., 1994. Comparison of geochemical indices used for the interpretation of paleoredox conditions in ancient mudstones. Chemical Geology 111, 111-129. DOI $10.1016 / 0009-2541(94) 90085-X$

Kaiho, K., Oshima, N., Adachi, K., Adachi, Y., Mizukami, T., Fujibayashi, M., Saito, R., 2016. Global climate change driven by soot at the K-Pg boundary as the cause of the mass extinction. Sci. Rep. 6 , 28427; doi: 10.1038/srep28427.

Katz, B.J., 1995. A survey of rift basin source rocks, in J. J. Lambiase, ed., Hydrocarbon habitat of rift basins: Geological Society (London) Special Publication 80, p. 213- 242.

Katz, B.J., 2005. Controlling factors on source rock development: review of productivity, preservation, and sedimentation rate. In: Harris, N.B. (Ed.), The Deposition of Organic-carbon-rich Sediments: Models, Mechanisms and Consequences. Special Publications of SEPM, pp. 7-16.

Kump, L.R., 1991. Interpreting carbon-isotope excursions-Strangelove oceans. Geol. 19, 299-302.

Lambiase, J. J., 1990, A model for tectonic control of lacustrine stratigraphic sequences in continental rift basins, in B. J. Katz, ed., Lacustrine basin exploration; case studies and modern analogs: AAPG Memoir 50, p. 265- 276.

Ma, P., Wang, L., Wang, C., Wu, X., Wei, Y., 2015. Organic-matter accumulation of the lacustrine Lunpola oil shale, central Tibetan Plateau: controlled by the paleoclimate, provenance, and drainage system. Int. J. Coal Geol. 147, 58-70.

Ma, Y., Fan, M., Lu, Y., Liu, H., Hao, Y., Xie, Z., Liu, Z., Peng, L., Du, X., Hu, H., 2016. Climate-driven paleolimnological change controls lacustrine mudstone depositional process and organic matter 
accumulation: constraints from lithofacies and geochemical studies in the Zhanhua Depression, eastern China. Int. J. Coal Geol. 167, 103-118.

Marquillas, R., Sabino, I., Sial, A.N., Del Papa, C., Ferreira, V., Matthews, S., 2007. Carbon and oxygen isotopes of Maastrichtian-Danian shallow marine carbonates: Yacoraite Formation, northwestern Argentina. Journal of South American Earth Sciences 23: 304-320.

Marquillas, R.A., Salfity, J.A., Matthews, S.J., Matteini, M., Dantas, E., 2011. U-Pb zircon age of the Yacoraite Formation and its significance to the Cretaceous-Tertiary boundary in the Salta Basin, Argentina. In Salfity JA and Marquillas RA ads., Cenezoic Geology of the Central Andes of Argentina, SCS Publisher, 227-246.

Mayor, A.G., Kefi, S., Bautista, S., Rodriguez, F., Carteni, F., Rietkerk, M., 2013. Feedbacks between vegetation pattern and resource loss dramatically decrease ecosystem resilience and restoration potential in a simple dryland model. Landscape Ecology, 28 (5), pp. 931-942.

Meyers, P.A., 1992. Changes in organic carbon stable isotope ratios across the K-T boundary. Global or local control. Chem. Geol. 101, 283-291.

Meyers, P.A., 1997. Organic geochemical proxies of paleoceanographic, paleolimnologic, and paleoclimatic processes. Organic Geochemistry, v. 27, p. 213-250.

Moroni, A.M., 1982. Correlacion palinologica en las Formaciones Olmedo y Yacoraite. Cuenca del Noroeste Argentino. 3rd Congr Geol Chil: 340-349.

Müller, W., Shelley, M., Miller, P., Broude, S., 2009. Initial performance metrics of a new custom designed ArF excimer LA-ICPMS system coupled to a two-volume laser-ablation cell. J. Anal.At. Spectrom., 2009, 24, 209-214. 
Nagao, S., and Nakashima, S., 1992. Possible complexation of uranium with dissolved humic substances in pore water of marine sediments. Science of the Total Environment 118, 439-447. DOI 10.1016/0048-9697(92)90109-6

Paquette, J.L., Tiepolo, M., 2007. High resolution (5 $\mu \mathrm{m})$ U-Th-Pb isotopes dating of monazite with excimer laser ablation (ELA)-ICPMS. Chem. Geol., 240, 222-237.

Paquette J-L, Barbosa JSF, Rohais S, Cruz SCP, Goncalves P, Peucat JJ, Leal ABM, Santos-Pinto M, Martin H, 2015. The geological roots of South America: 4.1 Ga and 3.7 Ga zircon crystals discovered in N.E. Brazil and N.W. Argentina. Precambrian Research, Vol. 271, 49-55

Peters, K. E., C. C. Walters, and J. M. Moldowan, 2006. The biomarker guide: v. 1- Biomarkers and isotopes in the environment and human history: Cambridge, United Kingdom, Cambridge University Press, $471 \mathrm{p}$.

Powell, W.G., Johston, P.A., Collom, C.J., 2003. Geochemical evidence for oxygenated bottom waters during deposition of fossiliferous strata of the Burgess Shale Formation. Palaeogeography, Palaeoclimatology, Palaeoecology 201, 249-268. DOI 10.1016/S0031-0182(03)00612-6

Pye, K. 1987. Aeolian Dust and Dust Deposits. 334 pp. Academic Press, San Diego.

Renne, P.R., Deino, A.L., Hilgen, F.J., Kuiper, K.F., Mark, D.F., Mitchell, W. S, Morgan, L.E., Mundil, R., Smit, J., 2013. Time scales of critical events around the Cretaceous-Paleogene boundary. Science, 339(6120): 684-687.

Rohais, S., Bonnet, S., Eschard, R., 2012. Sedimentary record of tectonic and climatic erosional perturbations in an experimental coupled catchment-fan system. Basin Research, 24: 198-212. doi: 10.1111/j.1365-2117.2011.00520.x 
Rohais, S., Barrois, A., Colletta, B., Moretti, I., 2016. Pre-salt to salt stratigraphic architecture in a rift basin: insights from a basin-scale study of the Gulf of Suez (Egypt). Arab. J. Geosci., 9, p. 317, $10.1007 / \mathrm{s} 12517-016-2327-8$

Romero-Sarmiento, M.-F., Ducros, M., Carpentier, B., Lorant, F., Cacas, M.-C., Pegaz-Fiornet, S., Wolf, S., Rohais, S., Moretti, Isabelle, 2013. Quantitative evaluation of TOC, organic porosity and gas retention distribution in a gas shale play using petroleum system modeling: application to the Mississippian Barnett Shale. Mar. Pet. Geol. 45, 315-330.

Romero-Sarmiento, M.-F., Rohais S., Littke R., 2019. Lacustrine Type I kerogen characterization at different thermal maturity levels: Application to the Late Cretaceous Yacoraite Formation in the Salta Basin - Argentina, International Journal of Coal Geology, Volume 203, Pages 15-27, ISSN 0166-5162, https://doi.org/10.1016/j.coal.2019.01.004.

Schwarzkopf, T.A., 1993. Model for prediction of organic carbon in possible source rocks: Marine and Petroleum Geochemistry, v. 10, p. 478-492.

Sial, A.N., Ferreira, V.P., Toselli, A.J., Parada, M.A., Acenolaza, F.G., Pimentel, M M., Alonso, R.N., 2001. Carbon and oxygen isotope compositions of some Upper Cretaceous-Paleocene sequences in Argentina and Chile. International Geological Review, 43, 892-909.

Speijer, R.P. and Van Der Zwaan, G.J., 1996. Extinction and survivorship of southern Tethyan benthic foraminifera across the Cretaceous/Paleogene boundary, in Biotic recovery from mass extinction events, edited by M. B., Hart, pp. 343-371, Geolog. Soc. Spec. Publ., 102, London.

Starck, D., 2011. Cuenca Cretácica-Paleógena del Noroeste Argentino. VIII Congreso de Exploración y Desarrollo de Hidrocarburos. Simposio de Cuencas Argentinas: visión actual: 407-453. Mar del Plata. Tao S, Xu Y, Tang D, Xu H, Li S, Chen S, Liu W, Yi Cui Y, Gou M, 2017. Geochemistry of the Shitoumei oil shale in the Santanghu Basin, Northwest China: Implications for paleoclimate conditions, 
weathering, provenance and tectonic setting. International Journal of Coal Geology, 184. 42-56. https://doi.org/10.1016/j.coal.2017.11.007

Toggweiler, J.R., 1989. Is the downward dissolved organic matter (DOM) flux important in carbon transport?, in Berger, W.H., Smetacek, V.S., and Wefer, G., eds., Productivity of the Ocean: Present and Past: Chichester, U.K., John Wiley \& Sons, p. 65-83.

Tribovillard, N., Algeo, T.J., Lyons, T., Riboulleau, A., 2006. Trace metals as paleoredox and paleoproductivity proxies: An update. Chem. Geol. 232, 12-32.

Tripathy, G.R., Singh, S.K., Ramaswamy, V., 2014. Major and trace element geochemistry of Bay of Bengal sediments: Implications to provenances and their controlling factors. Palaeogeography, Palaeoclimatology, Palaeoecology 397, 20-30. http://dx.doi.org/10.1016/j.palaeo.2013.04.012

Uliana, M.A., Legarreta, L., Laffitte, G. y H.J. Villar (1999). Estratigrafía y geoquímica de las facies generadoras de hidrocarburos en las cuencas petrolíferas Argentinas. Petrotecnia, Revista del Instituto Argentino del Petróleo y Gas, Año XL (3): 12-25. Buenos Aires

Vellekoop, J., Woelders, L, Açikalin, S., Smit, J., van de Schootbrugge, B., Yilmaz, I. Ö., Brinkhuis, H., Speijer, R.P., 2016. Ecological response to collapse of the biological pump following the mass extinction at the Cretaceous-Paleogene boundary. Biogeosciences Discuss., doi:10.5194/bg-2016-275 Whitfield, M., 2002. Interactions between phytoplankton and trace metals in the ocean. Adv. Mar. Biol. 41, 3-120.

Wignall, P.B., and Myers, K.J., 1988. Interpreting the benthic oxygen levels in mudrocks: a new approach. Geology 16, 452-455. DOI 10.1130/0091-7613(1988)016<0452:IBOLIM>2.3.CO;2

Zhang W, Yang W, Xie L, 2017. Controls on organic matter accumulation in the Triassic Chang 7 lacustrine shale of the Ordos Basin, central China. International Journal of Coal Geology, 183, 38-51. http://dx.doi.org/10.1016/i.coal.2017.09.015 


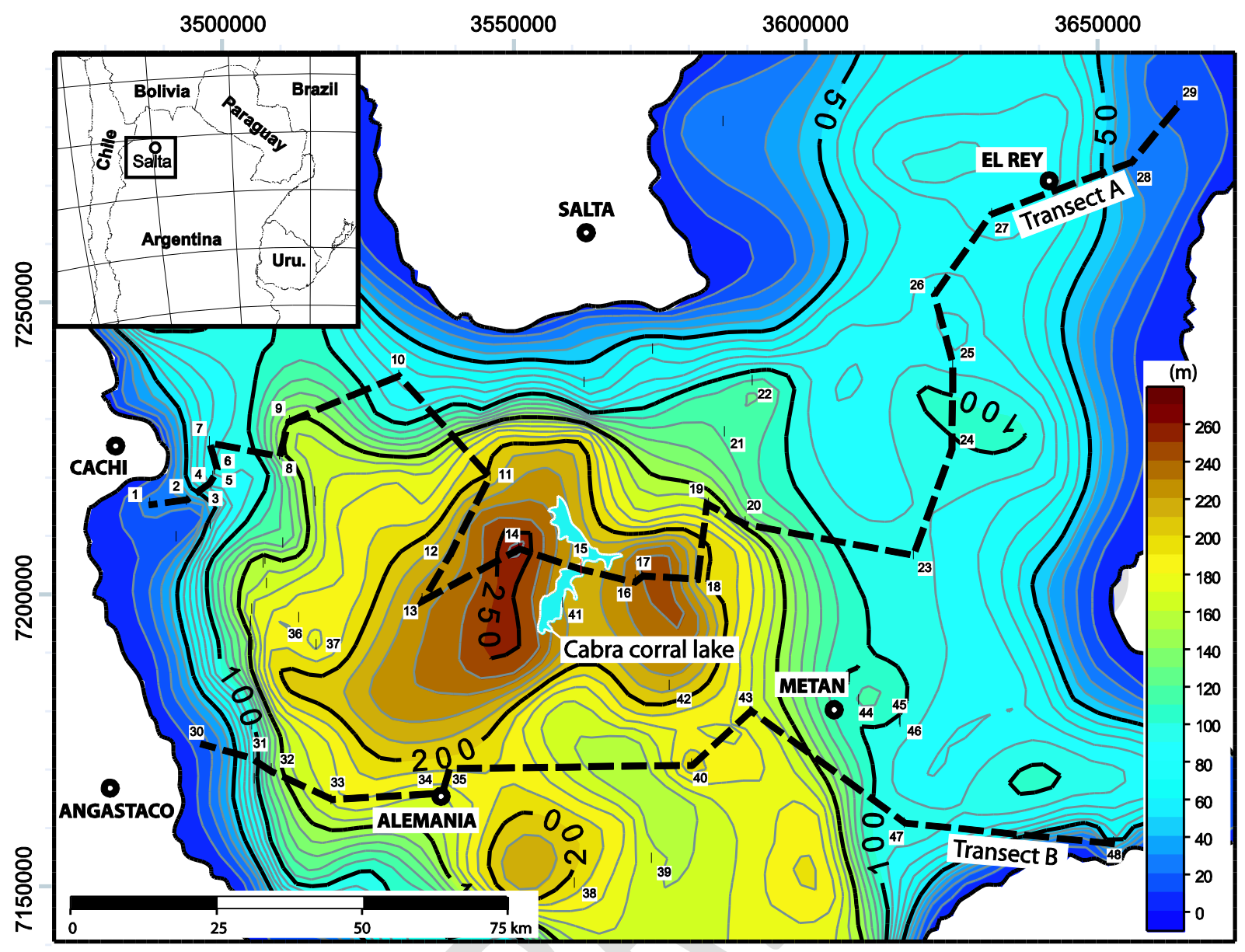

FIGURE 1 


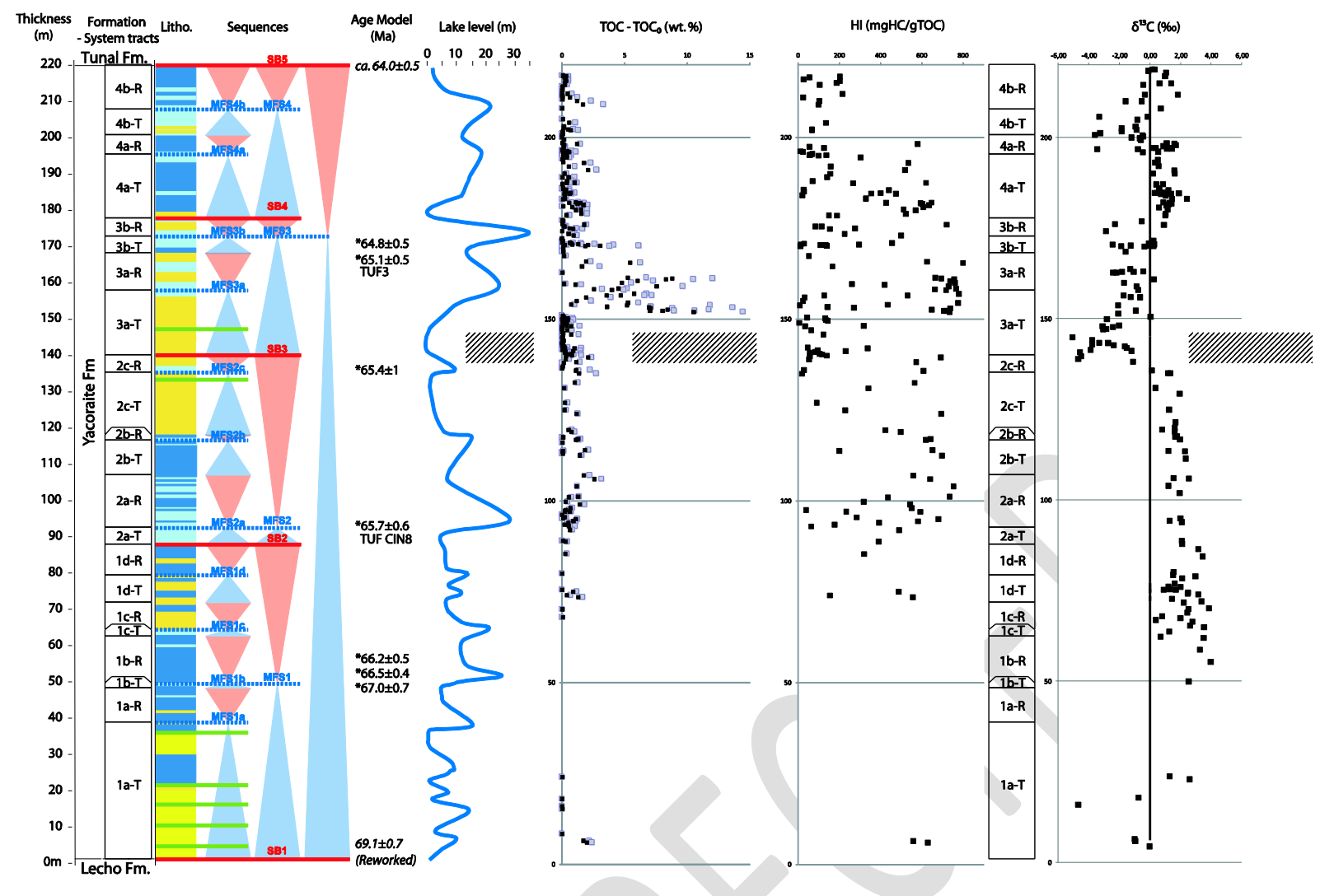

FIGURE 2 

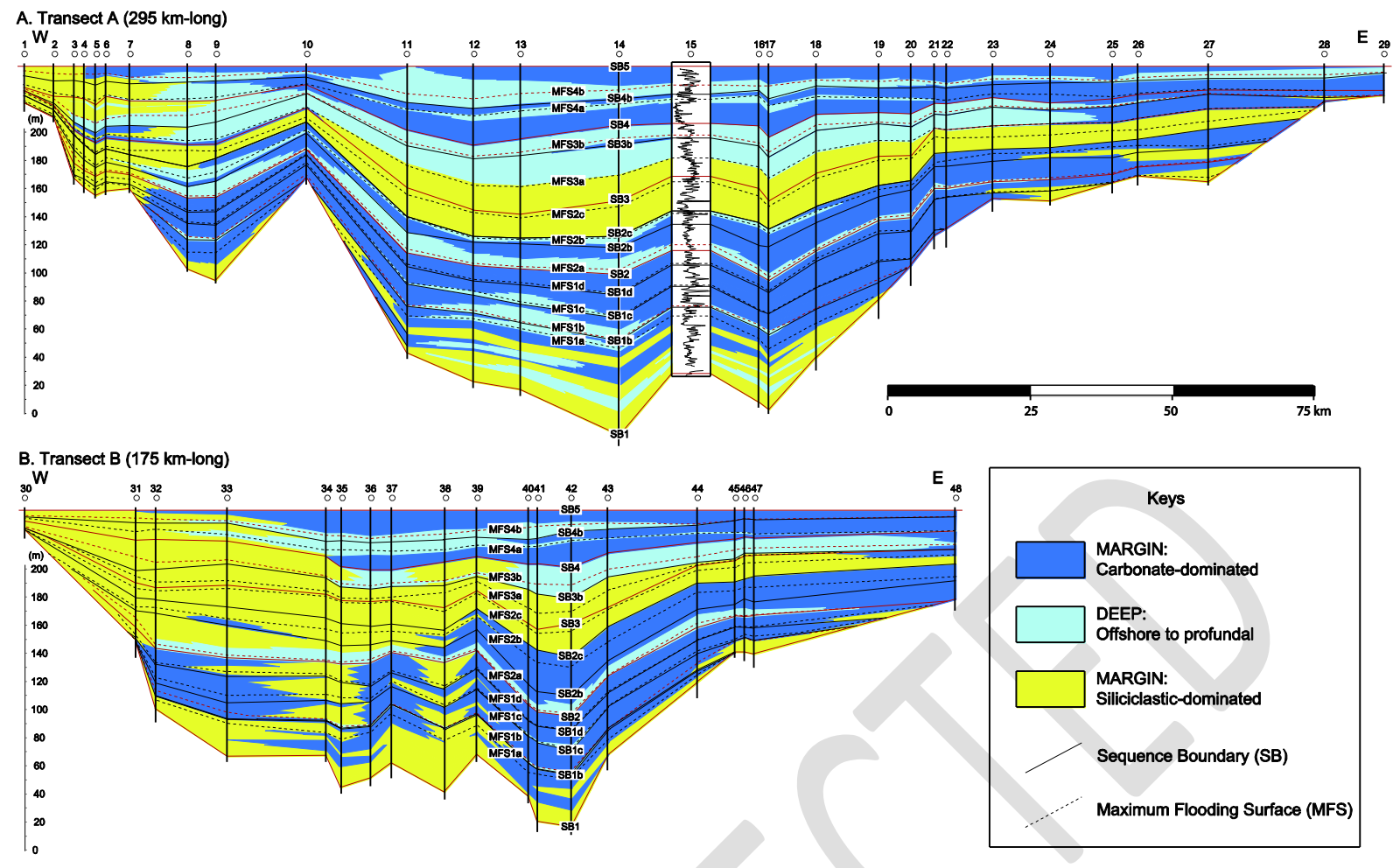

FIGURE 3 


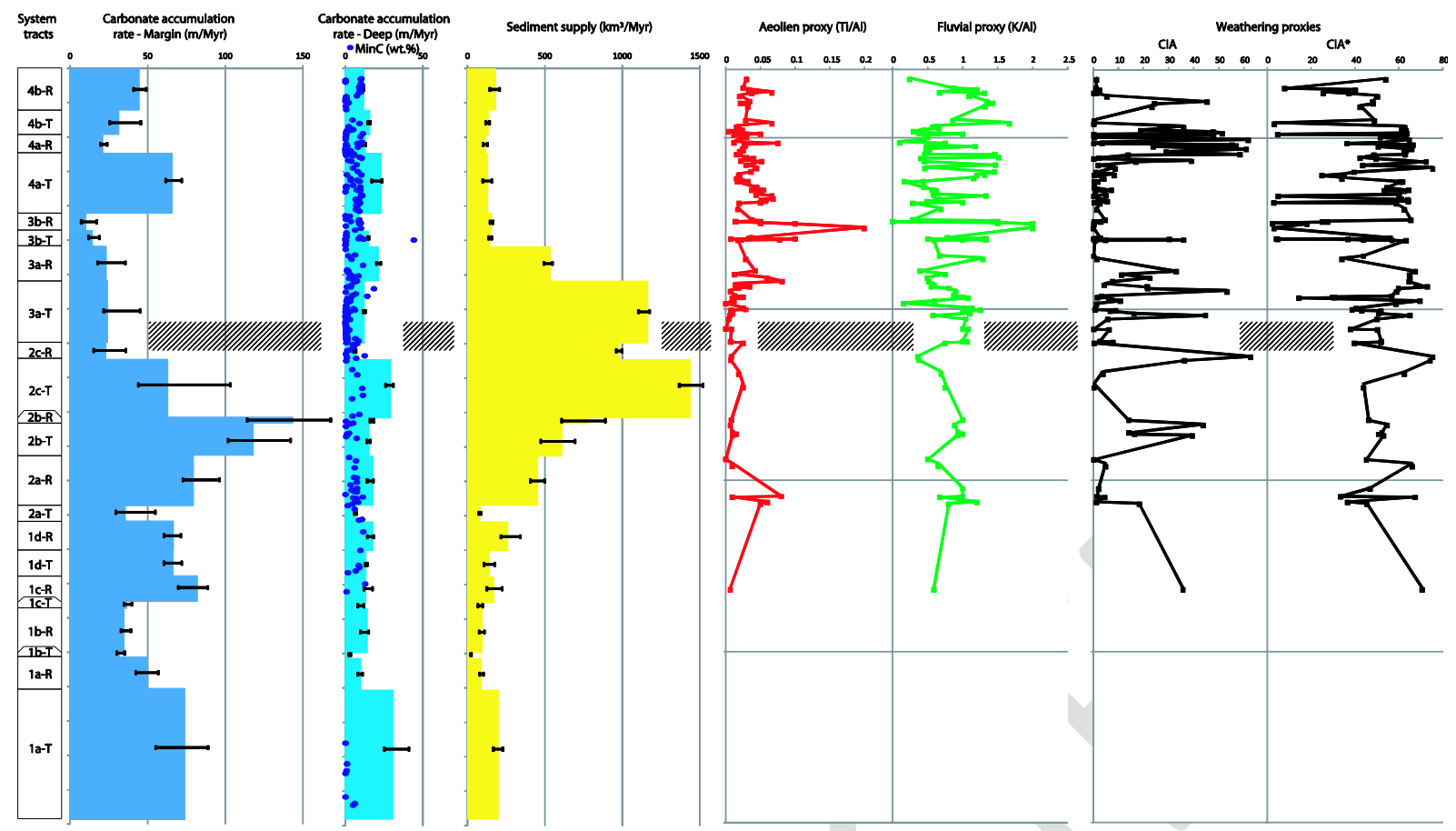

FIGURE 4 


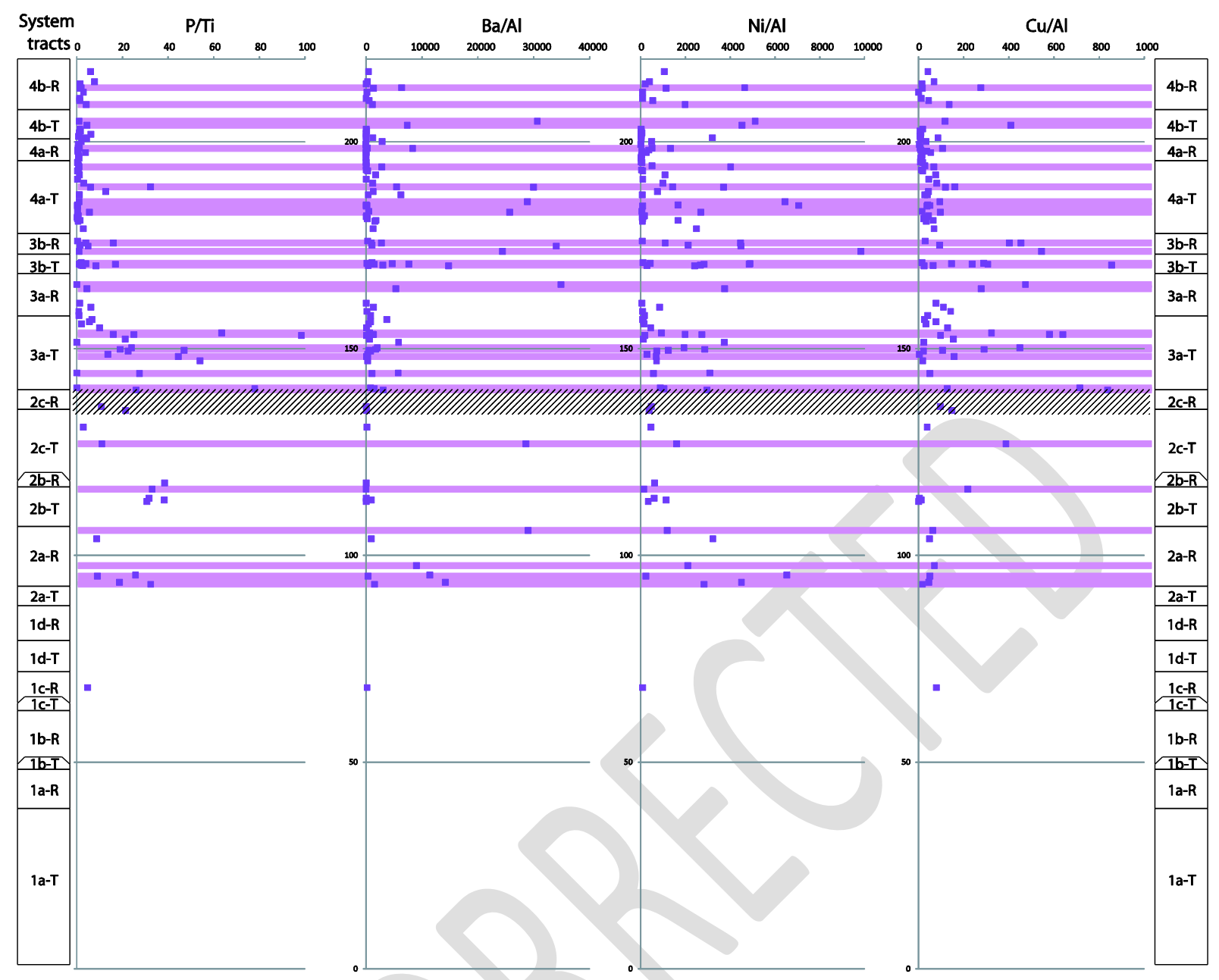

FIGURE 5 


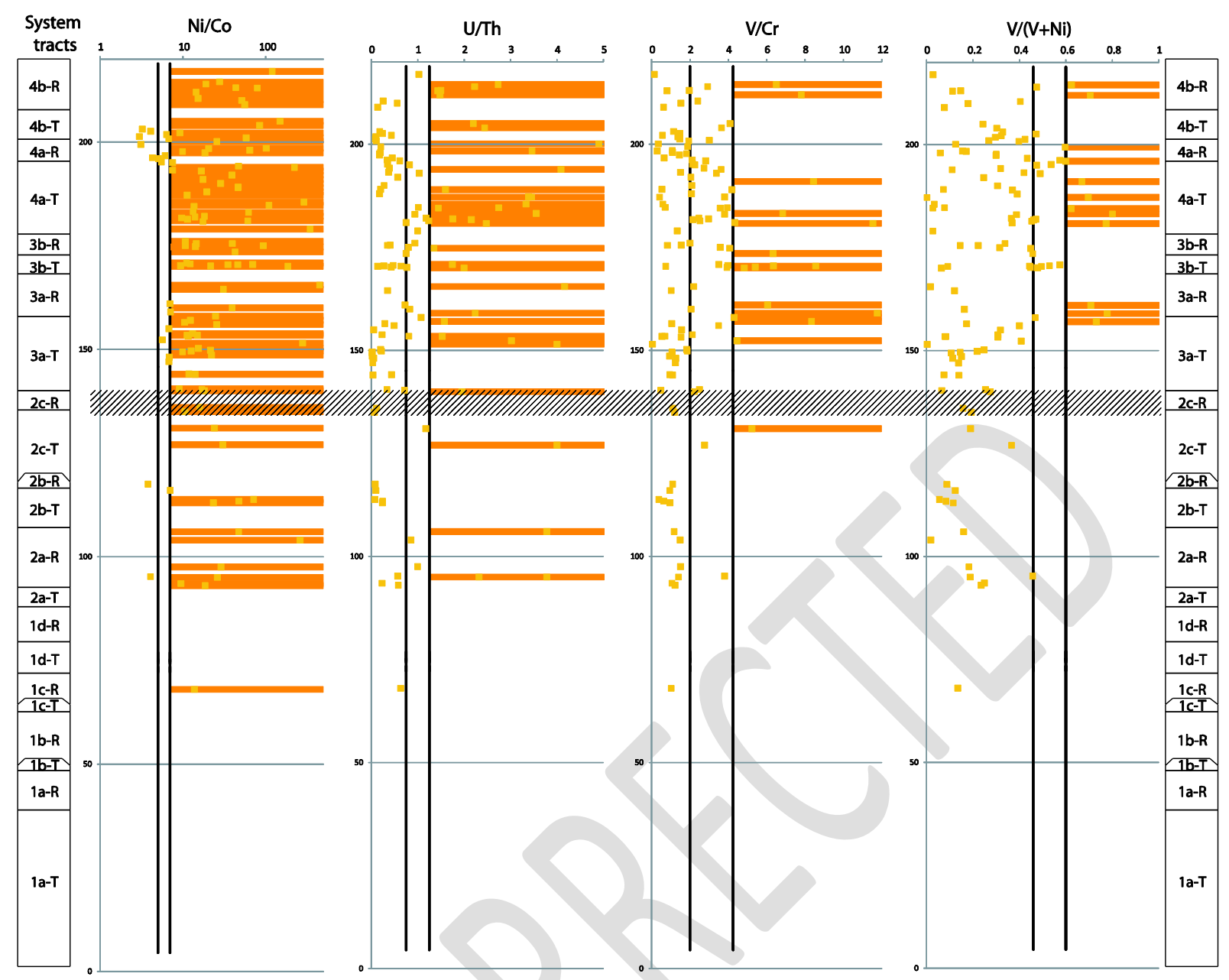

FIGURE 6 


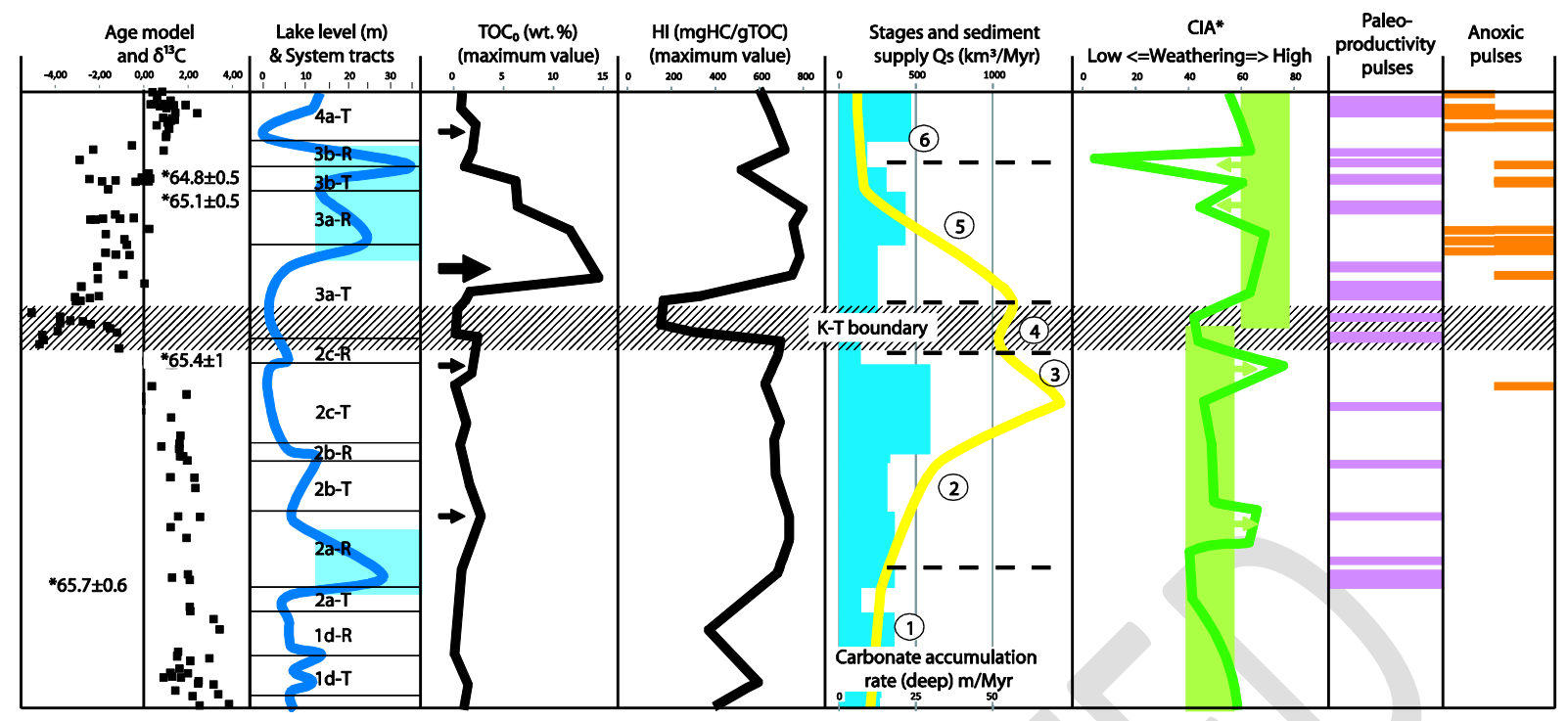

FIGURE 7 